\title{
HYDROGEOLOGIC INTERPRETATIONS OF NATURAL GAMMA LOGS FOR 31 SHALLOW WELLS IN THE MEMPHIS, TENNESSEE, AREA
}

By Eric W. Strom

\section{U.S. GEOLOGICAL SURVEY}

Water-Resources Investigations Report 97-4181

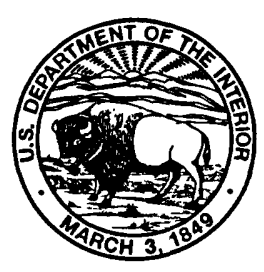

National Water-Quality Assessment Program

Jackson, Mississippi 


\section{U.S. DEPARTMENT OF THE INTERIOR \\ BRUCE BABBITT, Secretary \\ U.S. GEOLOGICAL SURVEY \\ Gorden P. Eaton, Director}

For additional information write to:

\section{District Chief}

U.S. Geological Survey 308 South Airport Road

Pearl, Mississippi 39208-6649
Copies of this report can be purchased from:

U.S. Geological Survey

Branch of Information Services Box 25286

Denver, CO 80225-0286

Information regarding the National Water-Quality Assessment (NAWQA) Program is available on the Internet via the World Wide Web. You may connect to the NAWQA Home Page using the Universal Resource Locator (URL) at:

http://wwwrvares.er.usgs.gov/nawqa/nawqa_home.html 


\section{FORWARD}

The mission of the U.S. Geological Survey (USGS) is to assess the quantity and quality of the earth resources of the Nation and to provide information that will assist resource managers and policymakers at Federal, State, and local levels in making sound decisions. Assessment of water-quality conditions and trends is an important part of this overall mission.

One of the greatest challenges faced by water-resources scientists is acquiring reliable information that will guide the use and protection of the Nation's water resources. That challenge is being addressed by Federal, State, interstate, and local water-resource agencies and by many academic institutions. These organizations are collecting water-quality data for a host of purposes that include: compliance with permits and water-supply standards; development of remediation plans for a specific contamination problem; operational decisions on industrial, wastewater, or water-supply facilities; and research on factors that affect water quality. An additional need for water-quality information is to provide a basis on which regional and national-level policy decisions can be based. Wise decisions must be based on sound information. As a society we need to know whether certain types of water-quality problems are isolated or ubiquitous, whether there are significant differences in conditions among regions, whether the conditions are changing over time, and why these conditions change from place to place and over time. The information can be used to help determine the efficacy of existing water-quality policies and to help analysts determine the need for and likely consequences of new policies.

To address these needs, the Congress appropriated funds in 1986 for the USGS to begin a pilot program in seven project areas to develop and refine the National Water-Quality Assessment (NAWQA) Program. In 1991, the USGS began full implementation of the program. The NAWQA Program builds upon an existing base of water-quality studies of the USGS, as well as those of other Federal, State, and local agencies. (See Map-21K) The objectives of the NAWQA Program are to:
- Describe current water-quality conditions for a large part of the Nation's freshwater streams, rivers, and aquifers.

- Describe how water quality is changing over time.

- Improve understanding of the primary natural and human factors that affect water-quality conditions.

This information will help support the development and evaluation of management, regulatory, and monitoring decisions by other Federal, State, and local agencies to protect, use, and enhance water resources.

The goals of the NAWQA Program are being achieved through ongoing and proposed investigations of 60 of the Nation's most important river basins and aquifer systems, which are referred to as study units. These study units are distributed throughout the Nation and cover a diversity of hydrogeologic settings. More than two-thirds of the Nation's freshwater use occurs within the 60 study units and more than twothirds of the people served by public watersupply systems live within their boundaries.

National synthesis of data analysis, based on aggregation of comparable information obtained from the study units, is a major component of the program. This effort focuses on selected waterquality topics using nationally consistent information. Comparative studies will explain differences and similarities in observed waterquality conditions among study areas and will identify changes and trends and their causes. The first topics addressed by the national synthesis are pesticides, nutrients, volatile organic compounds, and aquatic biology. Discussions on these and other water-quality topics will be published in periodic summaries of the quality of the Nation's ground and surface water as the information becomes available.

This world-wide-web site is an element of the comprehensive body of information developed as part of the NAWQA Program. The program depends heavily on the advice, cooperation, and information from many Federal, State, interstate, Tribal, and local agencies and the public. The assistance and suggestions of all are greatly appreciated.

Robert M. Hirsch Chief Hydrologist 


\section{CONTENTS}

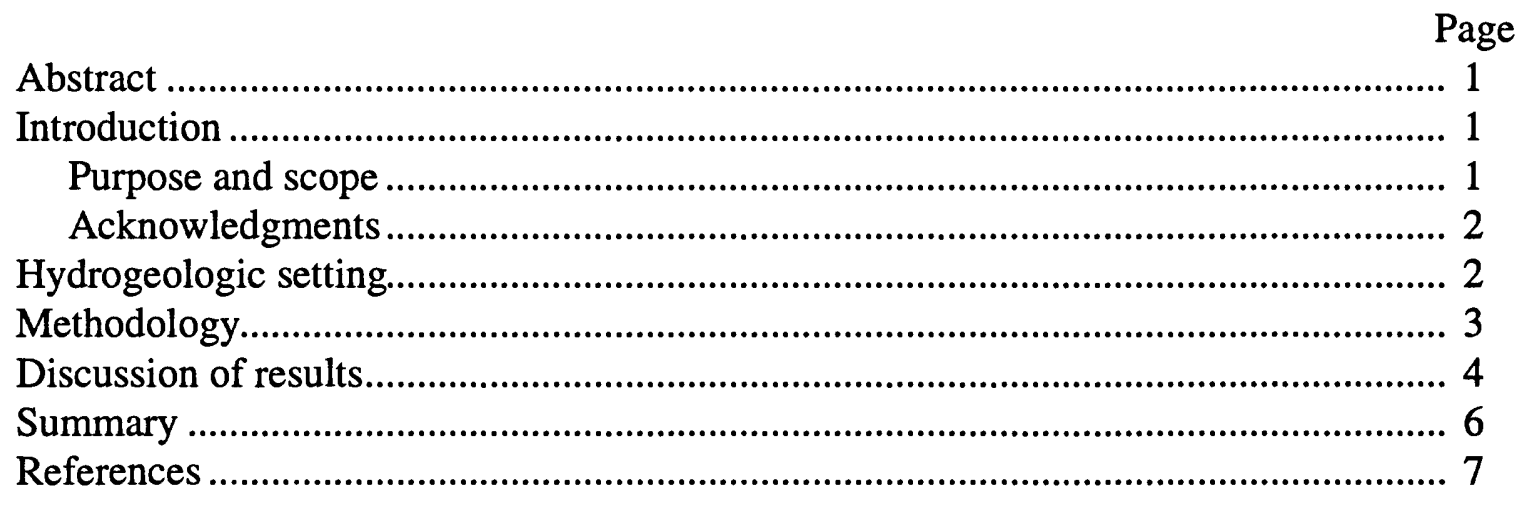

\section{ILLUSTRATIONS}

Figure 1. Map showing location of the Mississippi Embayment study unit .

2. Map showing location of monitoring wells in which natural-gamma logs were made.

3. Chart showing stratigraphy, lithology, and hydrologic significance of geologic units for which natural-gamma logs were made, Memphis, Tennessee, area.

4. Diagram showing idealized natural-gamma and lithologic logs and hydrogeologic interpretation for hydrogeologic units underlying the Memphis, Tennessee, area..

5-36. Diagrams showing natural-gamma and lithologic logs and hydrogeologic interpretation, Memphis, Tennessee, area for wells:

5. UR1

6. UR2

7. UR3

8. UR4

9. UR5

10. UR6

11. UR7

12. UR8

13. UR9

14. UR 10

15. UR 11

16. UR12

17. UR13M

18. UR13S

19. UR16

20. UR17

21. UR18

22. UR19 


\section{ILLUSTRATIONS-Continued}

23. UR20

24. UR21

25. UR22

26. UR23 33

27. UR24

28. UR25M

29. UR25S

30. UR26

31. UR27

32. UR 28

33. UR29

34. UR30

35. UR31

\section{CONVERSION FACTORS AND VERTICAL DATUM}

\section{Multiply}

foot

foot per minute

inch $\underline{\text { By }}$

0.3048

0.3048

25.4

\section{To obtain}

meter

meter per minute

millimeter

Sea level: In this report "sea level" refers to the National Geodetic Vertical Datum of 1929-a geodetic datum derived from a general adjustment of the first-order level nets of both the United States and Canada, formerly called Sea Level Datum of 1929.

GRAIN-SIZE CLASSIFICATION (from Wentworth, 1922)

\begin{tabular}{lc}
\hline \multicolumn{1}{c}{ Size class } & Grain size (millimeters) \\
\hline Gravel & $\geq 2$ \\
Very coarse sand & 1 to $<2$ \\
Coarse sand & 0.5 to $<1$ \\
Medium sand & 0.25 to $<0.5$ \\
Fine sand & 0.125 to $<0.25$ \\
Very fine sand & 0.0625 to $<0.125$ \\
Silt & 0.0039 to $<0.0625$ \\
Clay & $\leq 0.0039$ \\
\hline
\end{tabular}




\title{
HYDROGEOLOGIC INTERPRETATIONS OF NATURAL-GAMMA LOGS FOR 31 SHALLOW WELLS IN THE MEMPHIS, TENNESSEE, AREA
}

\author{
By Eric W. Strom
}

\begin{abstract}
In 1997 natural-gamma logs were made in 31 monitoring wells ranging from 30 to 109 feet in depth to determine the stratigraphy of the shallow hydrogeologic units in the Memphis, Tennessee, area. The hydrogeologic units studied in this investigation include the alluvium and loess of Holocene and Pleistocene age, the fluvial deposits of Pleistocene and Pliocene(?) age, and the Jackson Formation, Cockfield Formation, Cook Mountain Formation, and Memphis Sand of Eocene age. The gamma logs for these wells were interpreted by considering many sources of information, including published and unpublished geologic maps, logs based on auger cuttings and driller's information, potentiometric-surface maps, split-spoon samples, and the character of the gamma-log curves.

\section{INTRODUCTION}

In 1991, the U.S. Geological Survey (USGS) began full-scale implementation the National Water-Quality Assessment (NAWQA) program. The long-term goals of the NAWQA Program are to describe the status of and trends in the quality of a large part of the Nation's water resources and to identify the major natural and human factors that affect the quality of these resources. To achieve these goals, 60 hydrologic systems that include parts of most major river basins and aquifer systems were selected for study. The Mississippi Embayment study unit (MISE)(fig. 1) is one such hydrologic system (Mallory, 1994).

One of the issues under investigation within the MISE study area is the effect of urban development on the quality of shallow ground water in the Memphis, Tennessee, area. A shallow, unconfined to semi-confined aquifer consisting of

alluvial and fluvial deposits underlies most of the Memphis area. This shallow aquifer generally is separated from the deeper Memphis aquifer by a confining unit. The Memphis aquifer is the primary source of water supply for the city of Memphis. A network of 31 monitoring wells was installed within the uppermost aquifer of the Memphis area (fig. 2) so that samples could be collected and researchers could assess water quality. As part of this effort, natural-gamma logs were made in 31 monitoring wells ranging from 30 to 109 feet in depth to determine the stratigraphy of the hydrogeologic units.

\section{Purpose and Scope}

The purpose of this report is to describe the stratigraphy of the hydrogeologic units at each of the 31 monitoring wells. The report presents the natural-gamma-log data that were measured for the Mississippi
\end{abstract}


Embayment study unit monitoring wells in the Memphis, Tennessee, area and interpretations of these logs.

\section{Acknowledgments}

The author would like to thank William S. Parks (USGS) for significant technical contributions to this report; Gerard J. Gonthier (USGS) for providing sample data, field logs, and review; Larry B. Thomas and William K. Kelly (USGS) for their efforts in installing the monitoring wells; and Michael J. Mallory, William T. Oakley, and Bobby R. Richards (USGS) for their efforts in acquiring the gamma logs.

\section{HYDROGEOLOGIC SETTING}

The hydrogeologic units of interest to this investigation include the alluvium and loess of Holocene and Pleistocene age, the fluvial deposits of Pleistocene and Pliocene(?) age, and the Jackson Formation, Cockfield Formation, Cook Mountain Formation, and Memphis Sand of Eocene age (fig. 3). The lower part of the alluvium, the fluvial deposits, and the Memphis Sand are aquifers; the upper part of the alluvium, the loess, and the Cockfield and Cook Mountain Formations generally are confining units. The Jackson, Cockfield, and Cook Mountain Formations are referred to in this report as the "Jackson-upper Claiborne confining unit" after Parks (1990).

The alluvium consists of gravel, sand, silt, and clay that were deposited by streams. In the western part of the Memphis area, the alluvium comprises the Mississippi River alluvial aquifer, a regionally continuous and heavily pumped source of fresh water. Alluvium of interest to this investigation, however, consists of local deposits that underlie the alluvial plain of Nonconnah Creek.

Loess is predominantly composed of silt that has primarily been deposited by the wind. In Tennessee and southward into Mississippi, these deposits generally are thickest in the hills immediately adjacent to the eastern edge of the Mississippi River alluvial plain and thin eastward (Parks, 1993). Loess deposits encountered in this investigation generally ranged from 5 to 40 feet in thickness. In the Memphis area, loess deposits often contain geosols, which are relatively thin layers characterized by relatively high gamma-ray emissions (Parks, 1993).

The fluvial deposits consist primarily of sand and gravel transported and deposited by streams. These deposits occur beneath the uplands and valley slopes in the Memphis area, and are highly variable in thickness due to erosional surfaces at the top and base of the deposits (Graham and Parks, 1986). The fluvial deposits also have been referred to as "terrace deposits," the "water-table aquifer," or the "fluvial deposits aquifer" in the Memphis area. The fluvial deposits aquifer provides water to domestic and farm wells in rural areas (Parks, 1990).

The Jackson-upper Claiborne confining unit includes equivalents of the Jackson, Cockfield, and Cook Mountain Formations (fig. 3), which consist primarily of clay, silt, sand, and lignite. This confining unit generally separates the alluvium and fluvial deposits from the Memphis Sand in the Memphis area; however, the confining unit is highly variable in thickness and 
locally may be absent. The Jacksonupper Claiborne confining unit thins to the east until it is absent. The depositional extent of the confining unit occurs near the Shelby County boundary in the eastern part of the Memphis area (Parks, 1990).

The Memphis Sand consists primarily of a body of sand ranging from 650 to 900 feet in thickness with minor lenses of clay and silt (fig. 3). The Memphis Sand is stratigraphically equivalent to the Tallahatta Formation, Winona Sand, Zilpha Clay, and Sparta Sand of Mississippi, and the Carrizo Sand, Cane River Formation, and Sparta Sand of southern Arkansas (Hosman, 1988). The Memphis Sand is an aquifer that is regional in extent, generally under confined conditions, and the primary source of fresh water for the Memphis area and western Tennessee (Parks and Carmichael, 1990).

\section{METHODOLOGY}

Gamma radiation occurs naturally in geologic materials due to gammaemitting radioisotopes of potassium-40 and nuclides of the radium and thorium decay series. Measurements of naturalgamma radiation were made from January 27 to January 29,1997 , in 31 monitoring wells that had 2-inch polyvinyl chloride (pvc) casings and ranged from 30 to 109 feet in depth in the Memphis, Tennessee, area. A logger with a sodium iodide detector was used to measure natural-gamma radiation in counts per second. Because the rate at which the detection probe is lowered in the well affects the resolution of the acquired data, the probe was lowered at a constant rate of 15 feet per minute in all of the wells. The equipment was checked prior to field operations by logging a well with existing geologists' and natural-gamma logs and then comparing the results.

Gravel, sand, silt, and clay are the primary sediment types in the shallow subsurface of the Memphis, Tennessee, area. Therefore, the following general assumptions were applied in making interpretations: (1) clay and silt have the highest levels of gamma radiation; (2) sand and gravel have the lowest levels. Although these general assumptions may not be true elsewhere, they generally are confirmed for the Memphis area by analyses of split-spoon samples and geologists' logs.

Gamma logs made during this investigation were interpreted by considering many sources of information. Published and unpublished maps were used in determining the base of the alluvial and fluvial deposits (Parks, 1973, 1975, 1977, 1979, 1987, 1990) and the top of the Memphis Sand (Kingsbury and Parks, 1993). Logs based on auger cuttings and driller's information were used to aid in the interpretations of the natural-gamma and lithologic logs; however, auger cuttings are returned from depth to the surface and are subject to mixing with cuttings from overlying deposits. Therefore this information was used with caution.

All of the monitoring wells were screened at the bottom 10-foot interval. Potentiometric-surface maps of the Memphis aquifer (Kingsbury, 1996) and of the fluvial deposits aquifer (Parks, 1990) were helpful in determining the hydrogeologic unit in which the wells were screened by comparing the published water levels with water levels 
measured at each well at the time the gamma logs were made. It should be noted that the water-level measurements made during this investigation were taken prior to well development; however, the water levels from the monitoring wells were generally in agreement with published water levels from the corresponding aquifer. In addition, water levels measured just prior to and after well development were within 0.5 foot of agreement for each of the wells-the exception being the water level at UR26 which dropped more than 50 feet after the well was developed (G.J. Gonthier, USGS, written commun., 1997).

Two split-spoon samples, each measuring 2 feet in length, were generally taken at various depths during construction of each of the monitoring wells. The analyses of these samples provided a field calibration for interpreting the gamma logs for most of the wells.

Finally, the character of the curves produced by plotting counts per second of gamma radiation versus depth was used to determine the top and bottom altitudes of the hydrogeologic units. After analyzing all of the gamma logs, certain patterns emerged. An idealized log was created (fig. 4) to illustrate these general patterns. However, the thickness and presence of a particular hydrogeologic unit varies from well to well, as can the level of gamma radiation for a given hydrogeologic unit. Generally, the different hydrogeologic units encountered in this investigation produced different levels of gamma emissions. Therefore, transitions between hydrogeologic units generally are reflected on the gamma logs as either a gradual or sharp change in the slope of the curve. The depth to a change in hydrogeologic units generally was chosen at the midpoint of this slope of the curve on the gamma log produced by either the increasing or decreasing gamma emissions (see fig. 4 for examples). This placement of the depth to the change in hydrogeologic units is consistent with previous interpretations of gamma logs in the Memphis area (W.S. Parks, USGS, oral commun., 1997).

\section{DISCUSSION OF RESULTS}

The results of natural-gammaradiation measurements are plots of the number of counts per second of gamma radiation detected versus depth. Levels of naturally occurring gamma radiation vary not only with the type of geologic material encountered (such as clay or sand), but may also vary areally for the same type of geologic material. Therefore, the results of natural-gammaradiation measurements are subject to interpretation.

Several different factors were considered in interpreting each gamma log. However, the general criteria, based on the characteristics of the gamma curves, for determining the top and bottom elevations of the hydrogeologic units, as well as some general observations for the gamma logs (figs. 535) are as follows:

- The loess deposits in the Memphis area generally have a natural-gamma radiation level of about 50 to 80 counts per second. 
- A spike in the gamma logs occurs occasionally near the base of the loess deposits indicating a high level of gamma radiation for only a few feet of the layer's thickness. The spike may indicate a geosol, or "ancient soil" layer within the loess. Parks (1993) describes similar sharp increases in gamma radiation associated with geosols within loess deposits in the Memphis area. A spike is most apparent on logs of wells UR1, 2, 4, 8, 9 , and 10.

- The fluvial deposits generally are directly beneath the loess deposits. The top of the fluvial deposits generally is characterized by a gradual or sharp decrease in gamma emissions. A typical decrease is from about 60 or 70 to about 20 or 30 counts per second of gamma radiation. The best examples of a gradual decrease in gamma radiation with depth from loess to fluvial deposits are shown on logs for wells UR2, 3, 5, and 26. Examples of a sharp decrease in gamma radiation with depth from loess to fluvial deposits are shown on logs for wells UR6, 17, and 22.

- Logs based on auger cuttings and driller's information indicate a general coarsening of the fluvial deposits with depth. The gamma logs may reflect the coarsening of deposits with depth as gamma radiation decreases due to decreasing amounts of clay and silt which have relatively high levels of gamma radiation. Downward coarsening of grain size is characteristic of some fluvial deposits. Data from the lithologic logs and split-spoon samples indicate that, in the study area, the difference between sand and gravel cannot be determined from gamma logs.

-Within the fluvial deposits there is infrequently a spike in the gamma logs indicating a high level of gamma radiation for only a few feet of the layer's thickness. These spikes are interpreted to be clay lenses, but they may be concentrations of radioactive heavy minerals (such as monazite) in the sand (Parks, 1990). This spike is most apparent on logs for wells UR1, 23, 29, and 30.

- The Jackson-upper Claiborne confining unit generally is directly beneath the fluvial deposits. The top of the Jackson-upper Claiborne confining unit generally is characterized by a gradual or sharp increase in gamma emissions. The gammaradiation levels typically began at 10 or 20 counts per second and increase to more than 50 counts per second. These increases in levels of gamma radiation are due to increasing clay content as confirmed by lithologic logs and split-spoon samples. The best examples of a gradual increase in gamma 
radiation with depth are shown on logs for wells UR4, 9, 11, and 27. Examples of a sharp increase in gamma radiation with depth are shown on logs for wells 13S, 16, and 26.

- It is often very difficult to distinguish between the bottom of the Jackson-upper Claiborne confining unit and the top of the Memphis Sand. Parks (1990) notes that the upper part of the Memphis Sand is lithologically similar to the Jackson-upper Claiborne confining unit. In addition, the Jackson-upper Claiborne confining unit may also contain significant lenses of sand. Interpretations of the top of the Memphis Sand were based more heavily on maps from previous investigations (Parks, 1973, 1975, 1977, 1979, 1987, 1990; Kingsbury and Parks, 1993), on water-level measurements, and on the lithologic logs.

-Within the Memphis Sand there is occasionally a spike in the gamma logs indicating a high level of gamma radiation for only a few feet of the layer's thickness, similar to the spike infrequently observed in the fluvial deposits; these spikes are interpreted to be clay lenses. The spike is most apparent on logs for wells UR21, 22, and 24.

- Alluvial deposits were interpreted on several logs based on the physiography of the site. Wells UR13S, 13M,
$21,24,25 \mathrm{~S}, 25 \mathrm{M}$, and 31 are situated in the alluvial plain of Nonconnah Creek and are interpreted to have alluvial deposits as their shallowest hydrogeologic unit. Gamma logs of these deposits appear quite similar to the gamma logs of the loess deposits because much of the alluvium consists of reworked or colluviated loess.

The characteristics of the gamma-log curves and the observations discussed above may be used as a guide to understand the interpretations presented in this report. However, due to the somewhat subjective nature of gamma$\log$ interpretations, a different investigator may have a different interpretation of the tops and bottoms of the hydrogeologic units investigated in this study.

\section{SUMMARY}

In 1991, the U.S. Geological Survey began the NAWQA program to describe the status of and trends in the quality of a large part of the Nation's water resources and to identify the major natural and human factors that affect the quality of these resources. One of the issues under investigation within the Mississippi Embayment study unit is the effect of urban development on the quality of shallow ground water in the Memphis, Tennessee, area. A network of 31 monitoring wells was installed within the uppermost aquifer of the Memphis area so that samples could be collected and researchers could assess water quality. As part of this effort, naturalgamma logs were made in 31 monitoring wells ranging from 30 to 109 feet in 
depth to determine the stratigraphy of the hydrogeologic units. The hydrogeologic units of interest to this investigation include alluvium, loess, fluvial deposits, the Jackson Formation and upper part of the Claiborne Group, and the Memphis Sand. The gamma logs that were made during this investigation were interpreted by considering many sources of information, including published and unpublished geologic maps, logs based on auger cuttings and driller's information, potentiometric-surface maps, split-spoon samples, and the character of the gamma-log curves.

The loess deposits generally have a natural-gamma radiation level of about 50 to 80 counts per second. A spike in the gamma logs occurs occasionally near the base of the loess deposits indicating a high level of gamma radiation for only a few feet of the layer's thickness. The spike may indicate a geosol, or ancient soil layer within the loess.

The fluvial deposits generally are directly beneath the loess deposits. The top of the fluvial deposits generally is characterized by a gradual or sharp decrease in gamma emissions. Within the fluvial deposits there is infrequently a spike in the gamma logs indicating a high level of gamma radiation for only a few feet of the layer's thickness; these spikes are interpreted to be clay lenses. Logs based on auger cuttings and driller's information indicate a general coarsening of the fluvial deposits with depth. The gamma logs may reflect the coarsening of deposits with depth as gamma radiation decreases due to decreasing amounts of clay and silt which have relatively high levels of gamma radiation.
The Jackson-upper Claiborne confining unit generally is directly beneath the fluvial deposits. The top of the Jackson-upper Claiborne confining unit generally is characterized by a gradual or sharp increase in gamma emissions. It is often very difficult to distinguish between the bottom of the Jackson-upper Claiborne confining unit and the top of the Memphis Sand. The upper part of the Memphis Sand is lithologically similar to the Jacksonupper Claiborne confining unit. In addition, the Jackson-upper Claiborne confining unit may also contain significant lenses of sand. Within the Memphis Sand there is occasionally a spike in the gamma logs indicating a high level of gamma radiation for only a few feet of the layer's thickness, similar to the spike infrequently observed in the fluvial deposits. These spikes are interpreted to be clay lenses.

Alluvial deposits were interpreted on several logs based on the physiography of the site. Gamma logs of these deposits appear quite similar to gamma logs of the loess deposits because much of the alluvium consists of reworked or colluviated loess.

\section{REFERENCES}

Graham, D.D., and Parks, W.S., 1986, Potential for leakage among principal aquifers in the Memphis area, Tennessee: U.S. Geological Survey Water-Resources Investigations Report 85-4295, 46 p.

Hosman, R.L., 1988, Geohydrologic framework of the Gulf Coastal Plain: U.S. Geological Survey Hydrologic Investigations Atlas 695, scale $1: 1,500,000,2$ sheets. 
Kingsbury, J.A., 1996, Altitude of the potentiometric surfaces, September 1995, and historic water-level changes in the Memphis and Fort Pillow aquifers in the Memphis area, Tennessee: U.S. Geological Survey Water-Resources Investigations Report 96-4278, 1 sheet.

Kingsbury, J.A., and Parks, W.S., 1993, Hydrogeology of the principal aquifers and relation of faults to interaquifer leakage in the Memphis area, Tennessee: U.S. Geological Survey Water-Resources Investigations Report 93-4075, $18 \mathrm{p}$.

Mallory, M.J., 1994, National water quality assessment program-the Mississippi embayment: U.S. Geological Survey Fact Sheet FS-94-047.

Parks, W.S., 1973, Geologic map of the Southwest Memphis quadrangle, Tennessee: U.S. Geological Survey Open-File Report, scale 1:24,000.

1975, Geologic map of the Germantown quadrangle, Tennessee: U.S. Geological Survey Open-File Report 75-586, scale 1:24,000.

1977, Geologic map of the Ellendale quadrangle, Tennessee: U.S. Geological Survey Open-File Report 77-752, scale 1:24,000.

1979, Geologic map of the Northeast Memphis quadrangle, Tennessee: U.S. Geological Survey Open-File Report 791268 , scale $1: 24,000$.

1987, Geologic map of the Southeast Memphis quadrangle, Tennessee: Tennessee Division of Geology, GM 409-SW, scale 1:24,000.
1990, Hydrogeology and preliminary assessment of the potential for contamination of the Memphis aquifer in the Memphis area, Tennessee: U.S. Geological Survey Water-Resources Investigations Report 90-4092, 39 p.

1993 , Use of geophysical well logs to determine loess thicknesses and correlate loesses and geosols in the Memphis, Tennessee - northern Mississippi area: Mississippi Geology, v. 14 , no. 3 , p. 41-46.

Parks, W.S., and Carmichael, J.K., 1990, Geology and ground-water resources of the Memphis Sand in western Tennessee: U.S. Geological Survey Water-Resources Investigations Report $88-4182,30 \mathrm{p}$.

Wentworth, C.K., 1922, A scale of grade and class terms for clastic sediments: Journal of Geology, Vol. 30, p. 377-392. 


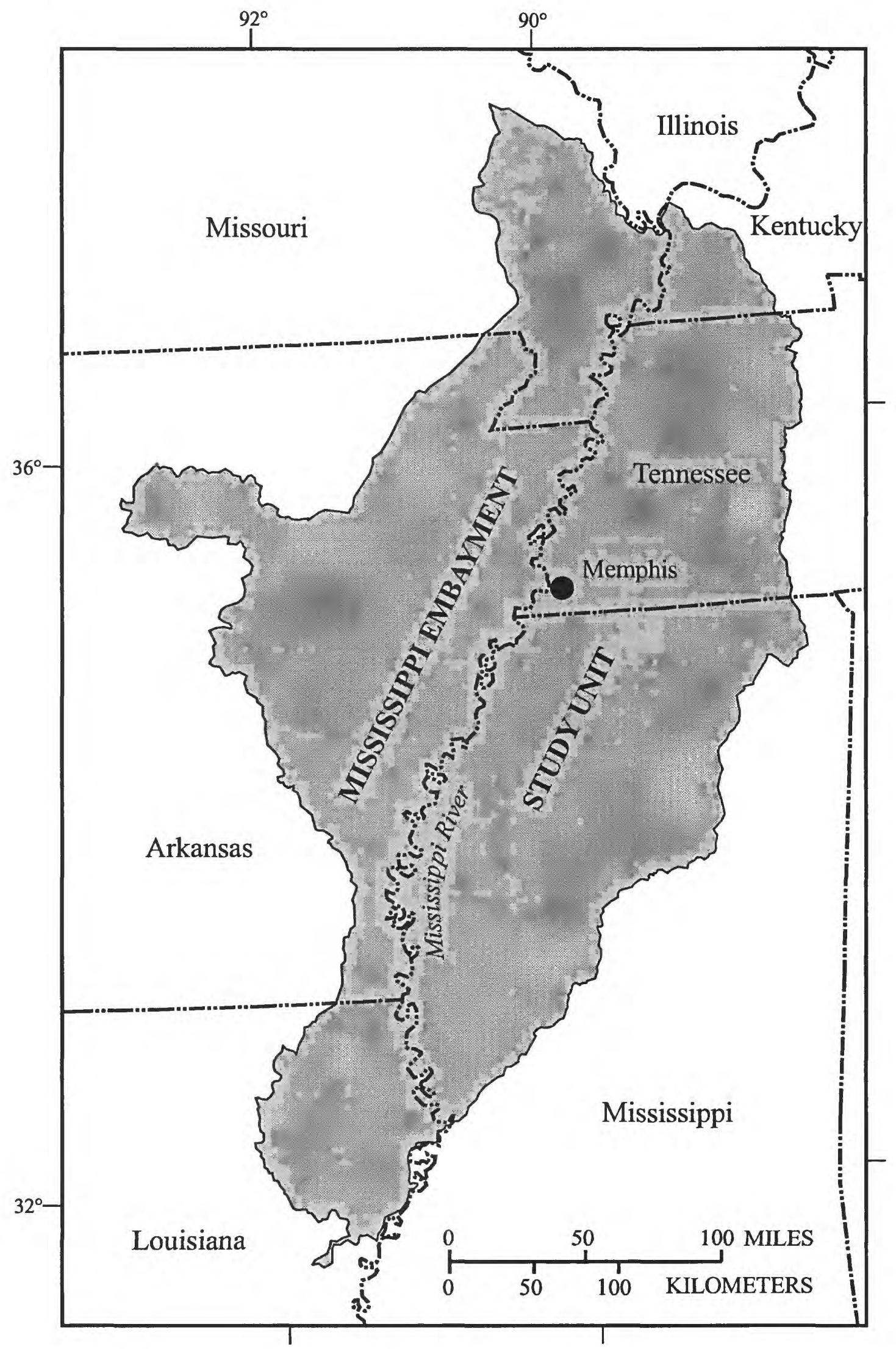

Figure 1. Location of the Mississippi Embayment study unit. 


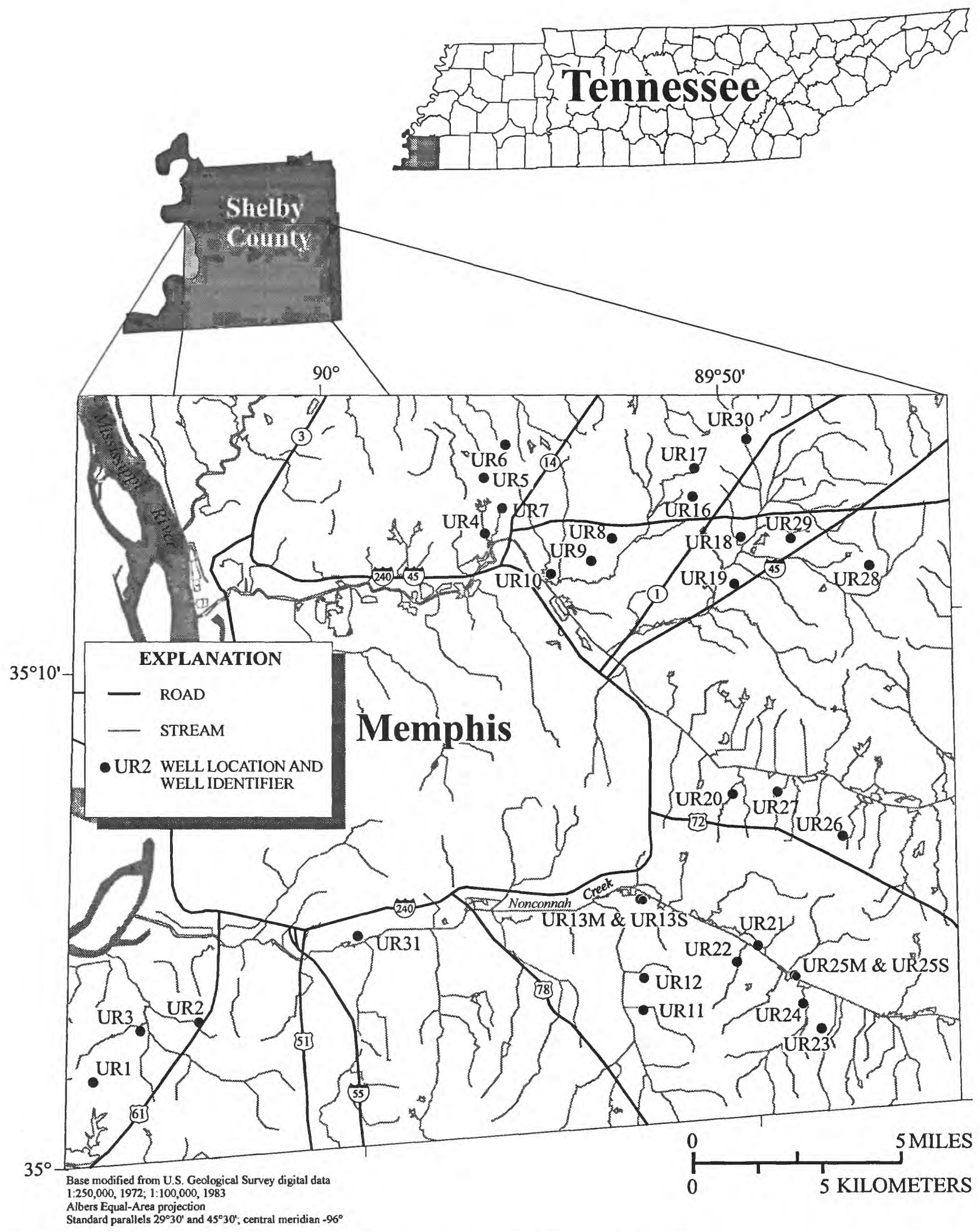

Figure 2. Location of monitoring wells in which natural-gamma logs were made. 


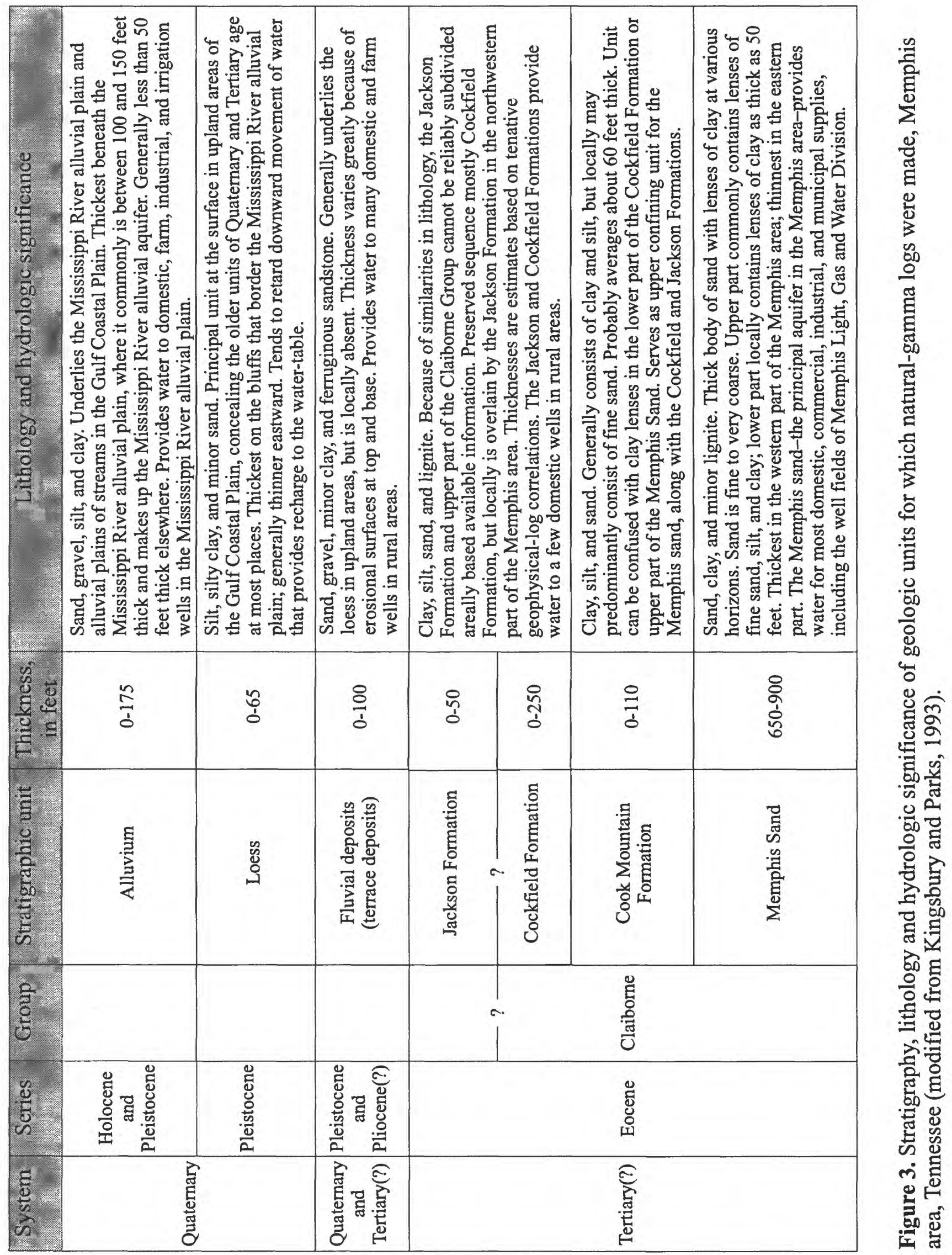



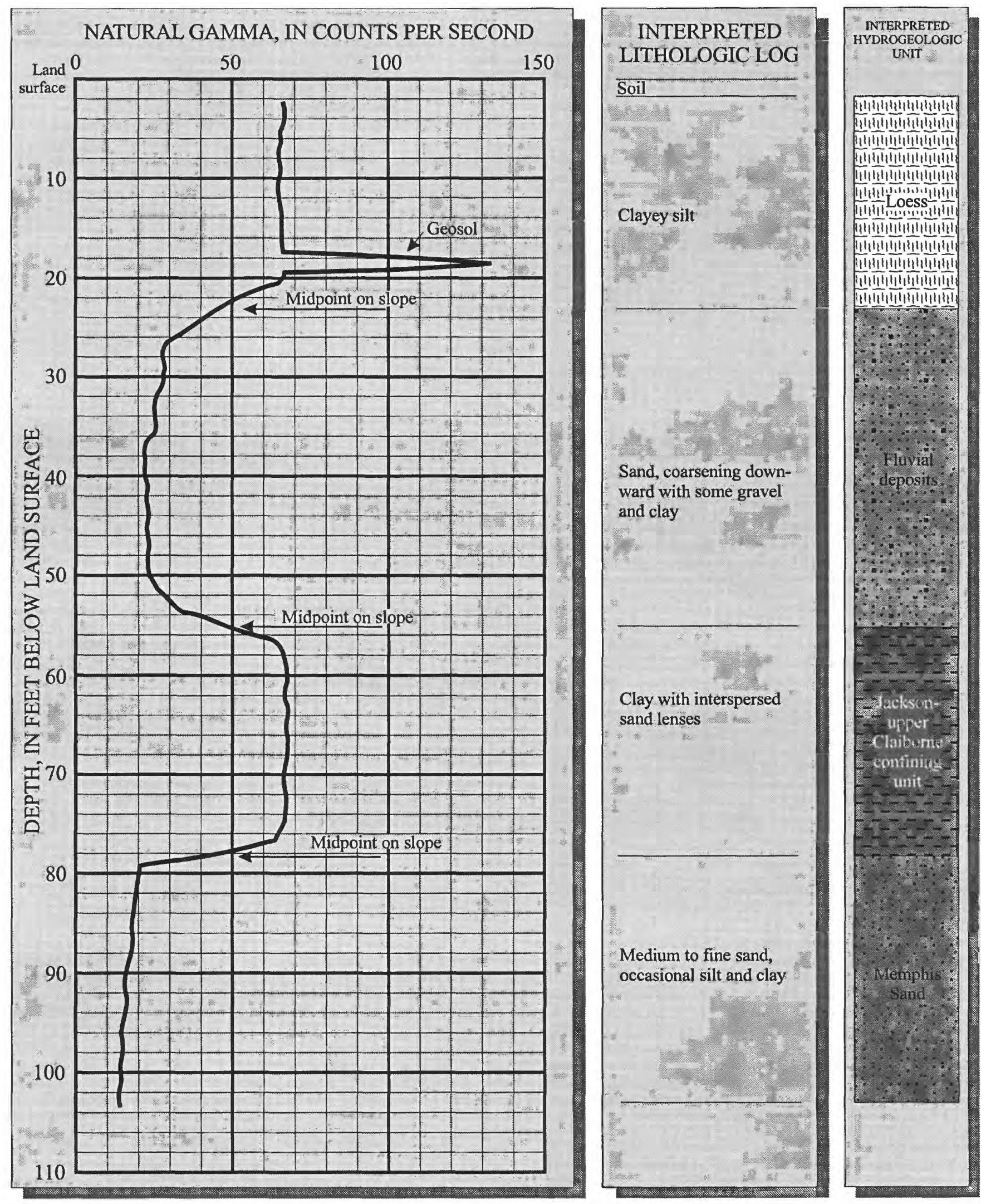

Figure 4. Idealized natural-gamma and lithologic logs and hydrogeologic interpretation for hydrogeologic units underlying the Memphis, Tennessee, area. 
Latitude: $35^{\circ} 01^{\prime} 49^{\prime \prime} \quad$ Longitude: $90^{\circ} 06^{\prime} 38^{\prime \prime}$ Altitude: 267 feet above sea level Total well depth: 70 feet
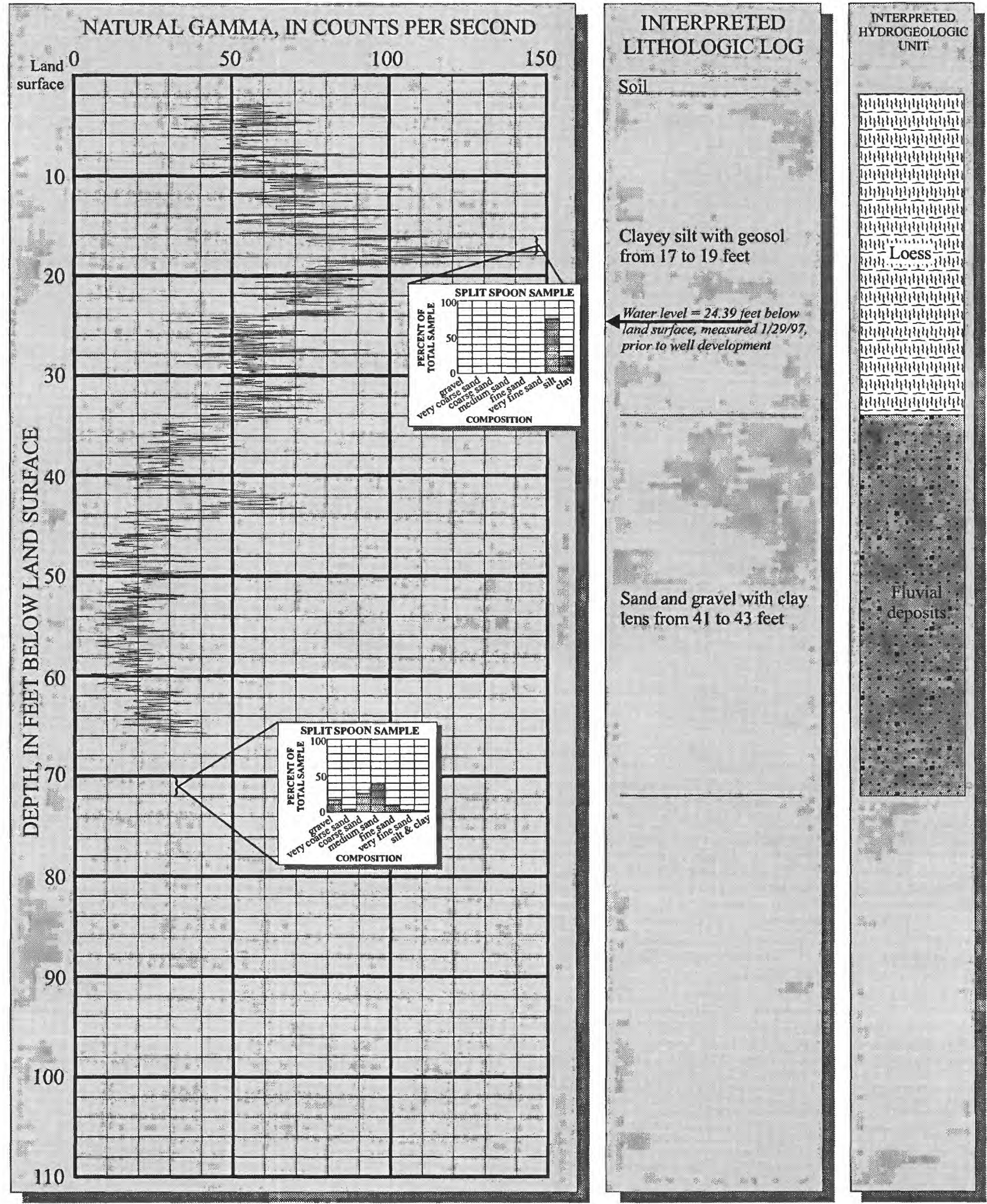

Figure 5. Natural-gamma and lithologic logs and hydrogeologic interpretation for well UR1, Memphis, Tennessee, area. 


\section{Well UR2}

Latitude: $35^{\circ} 02^{\prime} 45^{\prime \prime} \quad$ Longitude: $90^{\circ} 03^{\prime} 55^{\prime \prime}$ Altitude: 281 feet above sea level Total well depth: 68 feet

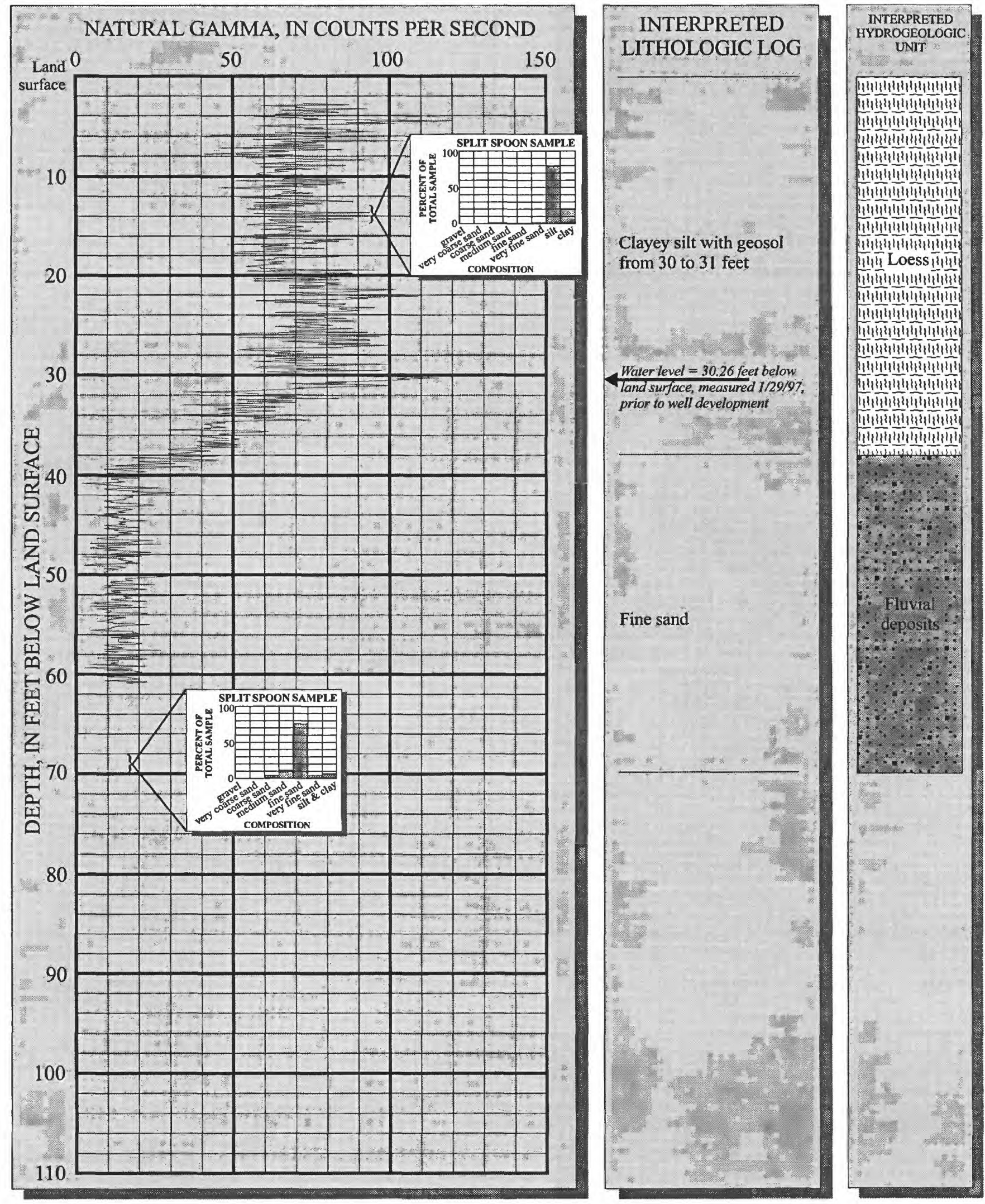

Figure 6. Natural-gamma and lithologic logs and hydrogeologic interpretation for well UR2, Memphis, Tennessee, area. 
Latitude: $35^{\circ} 02^{\prime} 42^{\prime \prime} \quad$ Longitude: $90^{\circ} 05^{\prime} 29^{\prime \prime}$ Altitude: 239 feet above sea level Total well depth: 68 feet

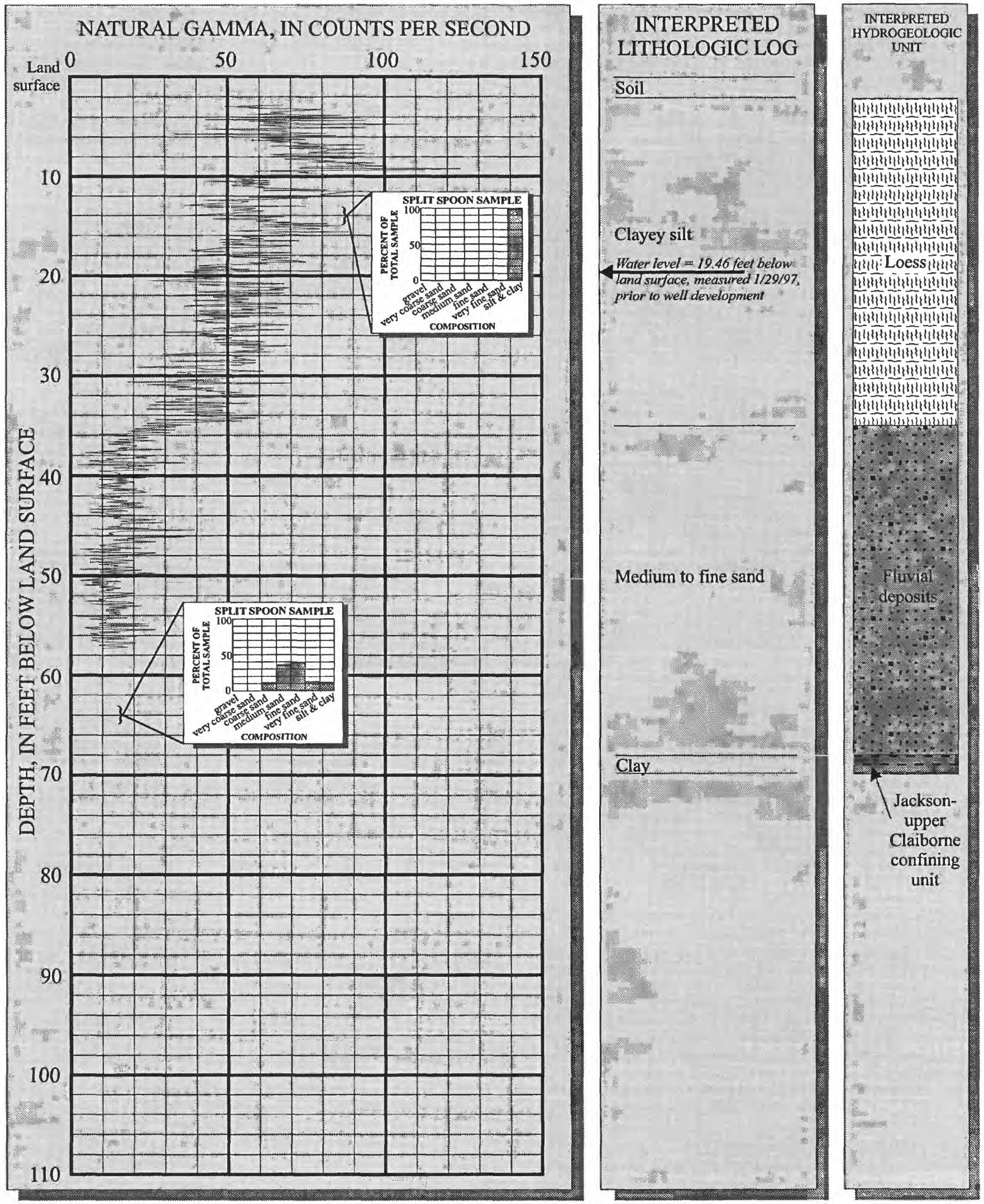

Figure 7. Natural-gamma and lithologic logs and hydrogeologic interpretation for well UR3, Memphis, Tennessee, area. 
Latitude: $35^{\circ} 12^{\prime} 17^{\prime \prime} \quad$ Longitude: $89^{\circ} 56^{\prime} 05^{\prime \prime}$ Altitude: 242 feet above sea level Total well depth: 38 feet

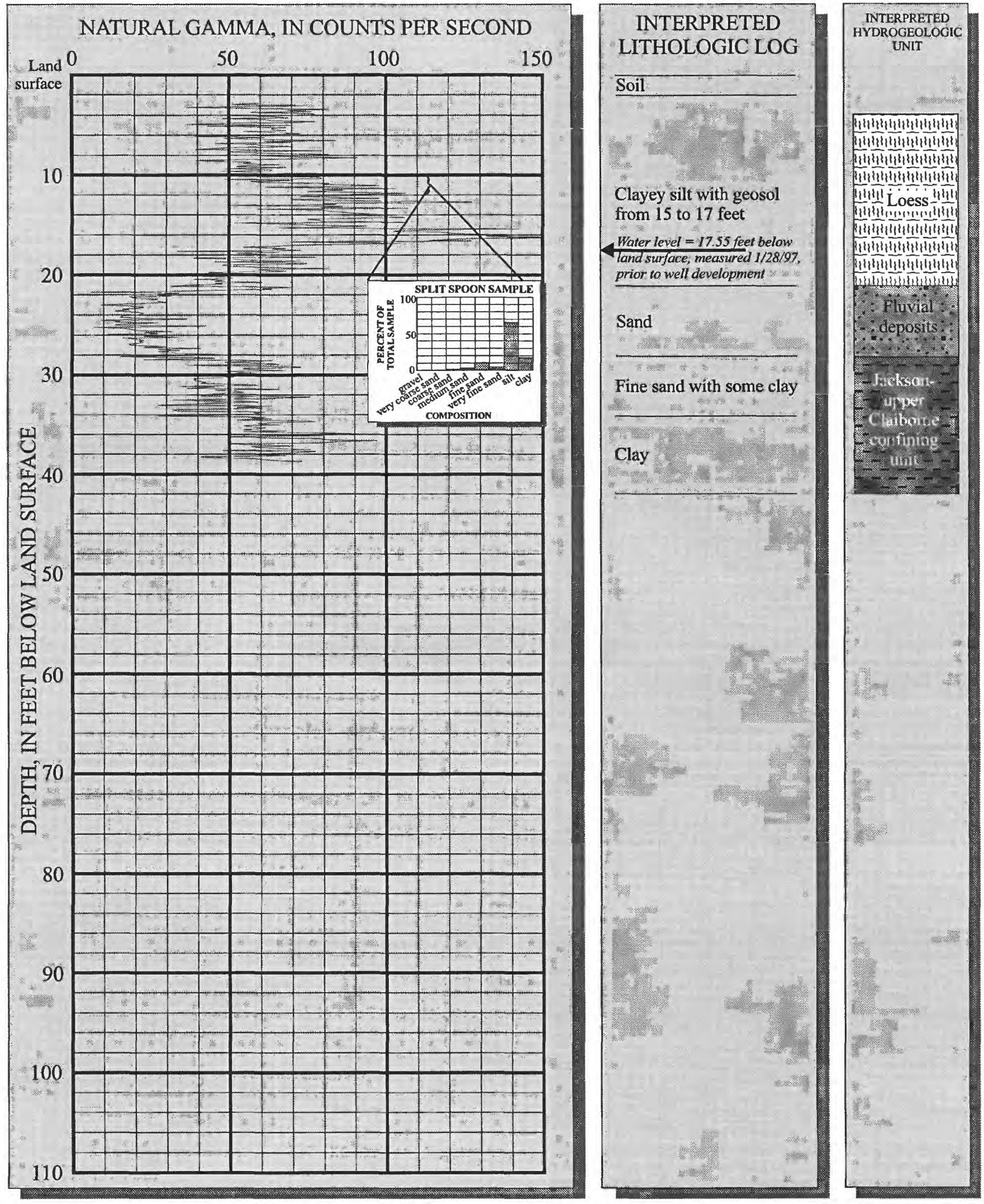

Figure 8. Natural-gamma and lithologic logs and hydrogeologic interpretation for well UR4, Memphis, Tennessee, area. 
Latitude: $35^{\circ} 13^{\prime} 24^{\prime \prime} \quad$ Longitude: $89^{\circ} 56^{\prime} 01^{\prime \prime}$ Altitude: 330 feet above sea level Total well depth: 46 feet

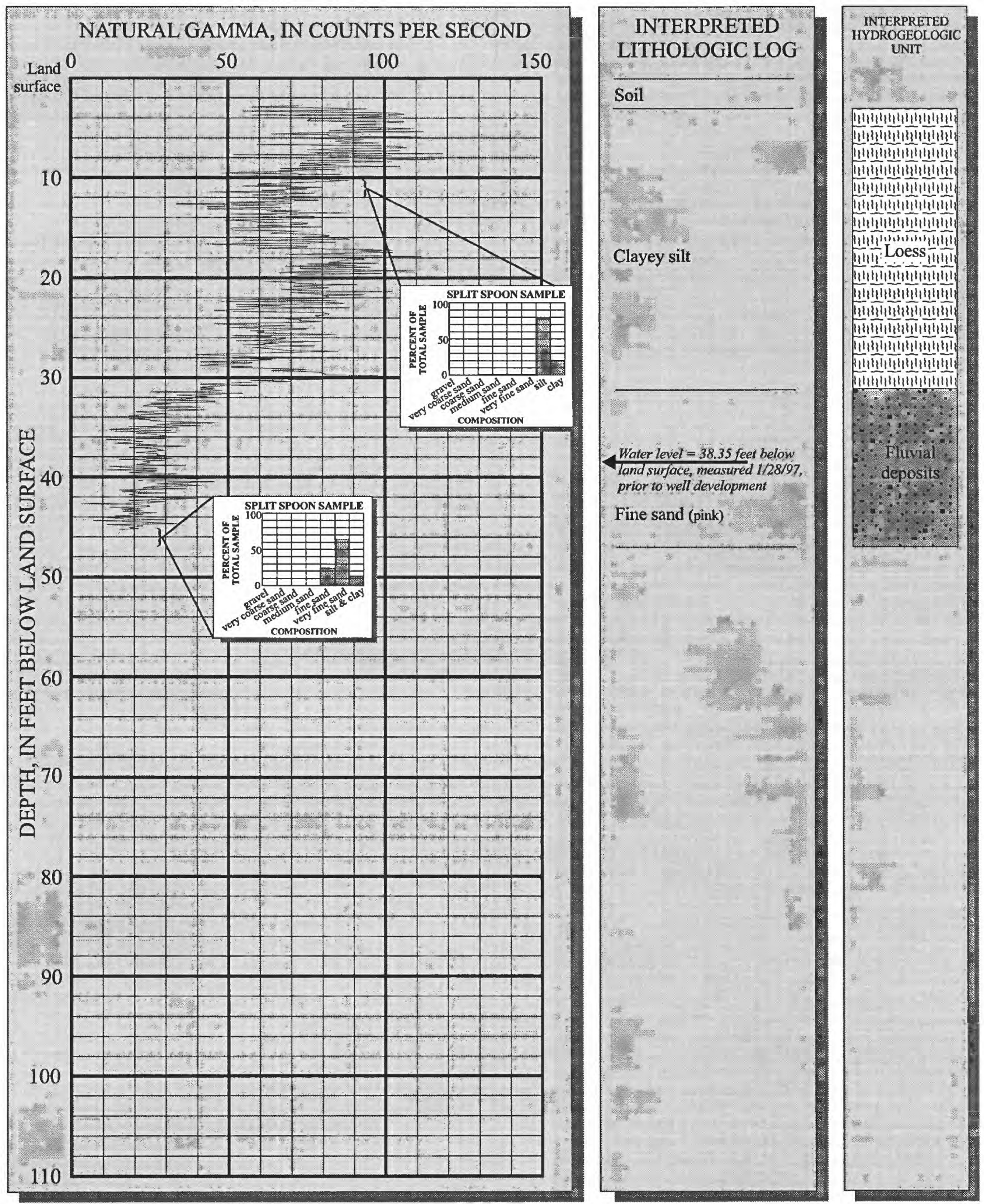

Figure 9. Natural-gamma and lithologic logs and hydrogeologic interpretation for well UR5, Memphis, Tennessee, area. 
Well UR6

Latitude: $35^{\circ} 14^{\prime} 02^{\prime \prime} \quad$ Longitude: $89^{\circ} 55^{\prime} 26^{\prime \prime}$ Altitude: 310 feet above sea level Total well depth: 40 feet

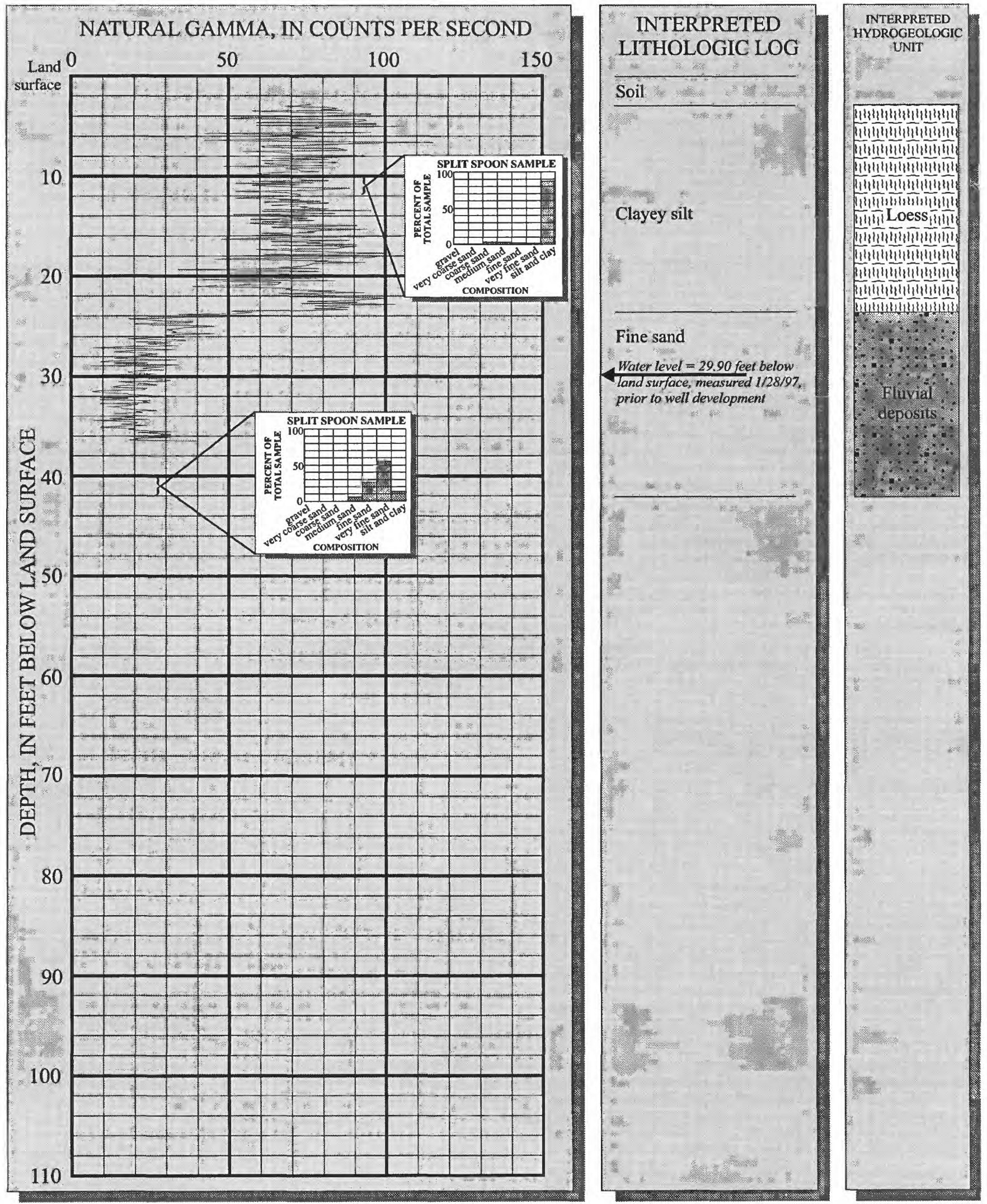

Figure 10. Natural-gamma and lithologic logs and hydrogeologic interpretation for well UR6, Memphis, Tennessee, area. 


\section{Well UR7}

Latitude: $35^{\circ} 12^{\prime} 46^{\prime \prime} \quad$ Longitude: $89^{\circ} 55^{\prime} 37^{\prime \prime}$ Altitude: 293 feet above sea level Total well depth: 49 feet

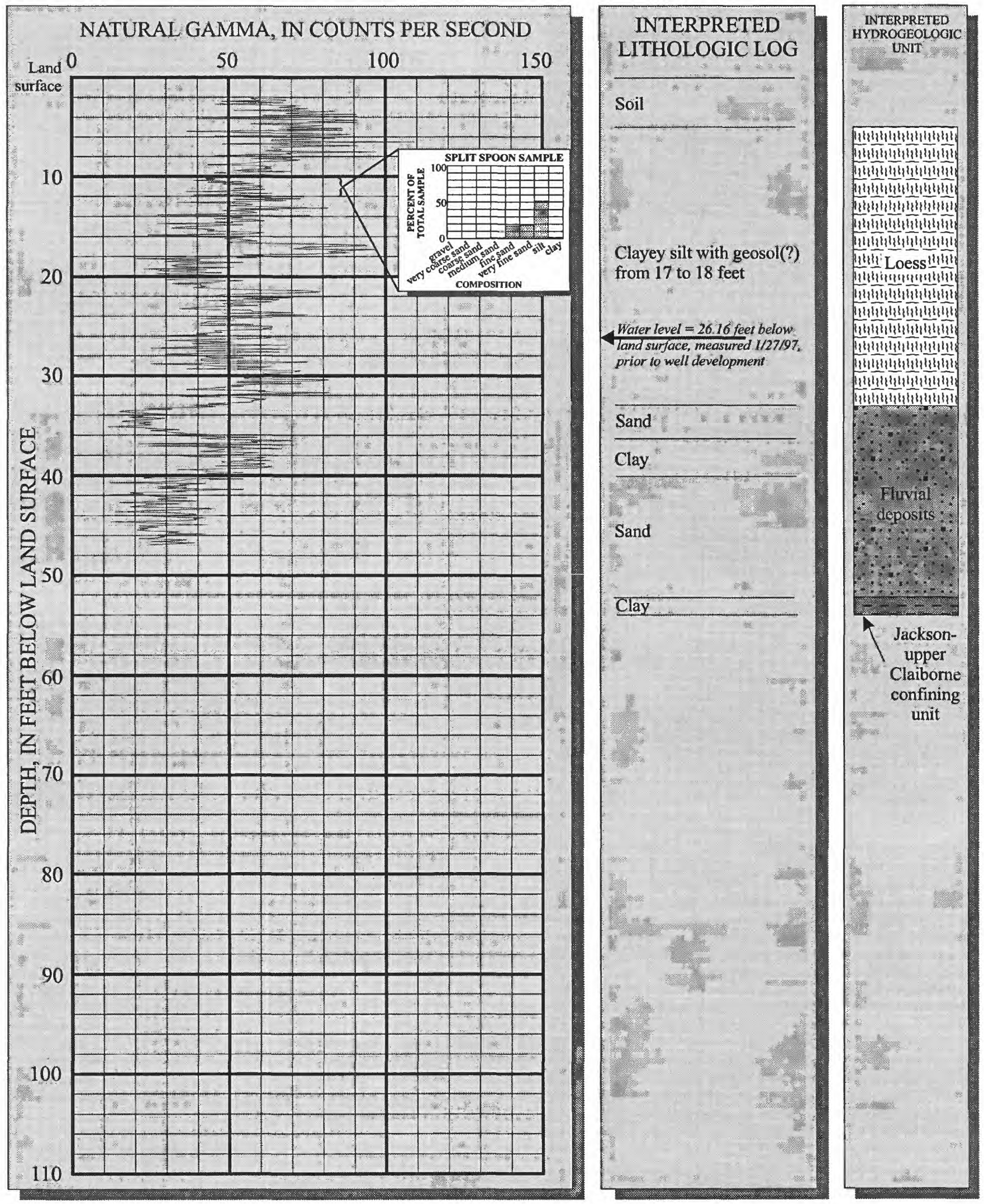

Figure 11. Natural-gamma and lithologic logs and hydrogeologic interpretation for well UR7, Memphis, Tennessee, area. 
Latitude: $35^{\circ} 12^{\prime} 01^{\prime \prime} \quad$ Longitude: $89^{\circ} 52^{\prime} 55^{\prime \prime}$ Altitude: 278 feet above sea level Total well depth: 44 feet

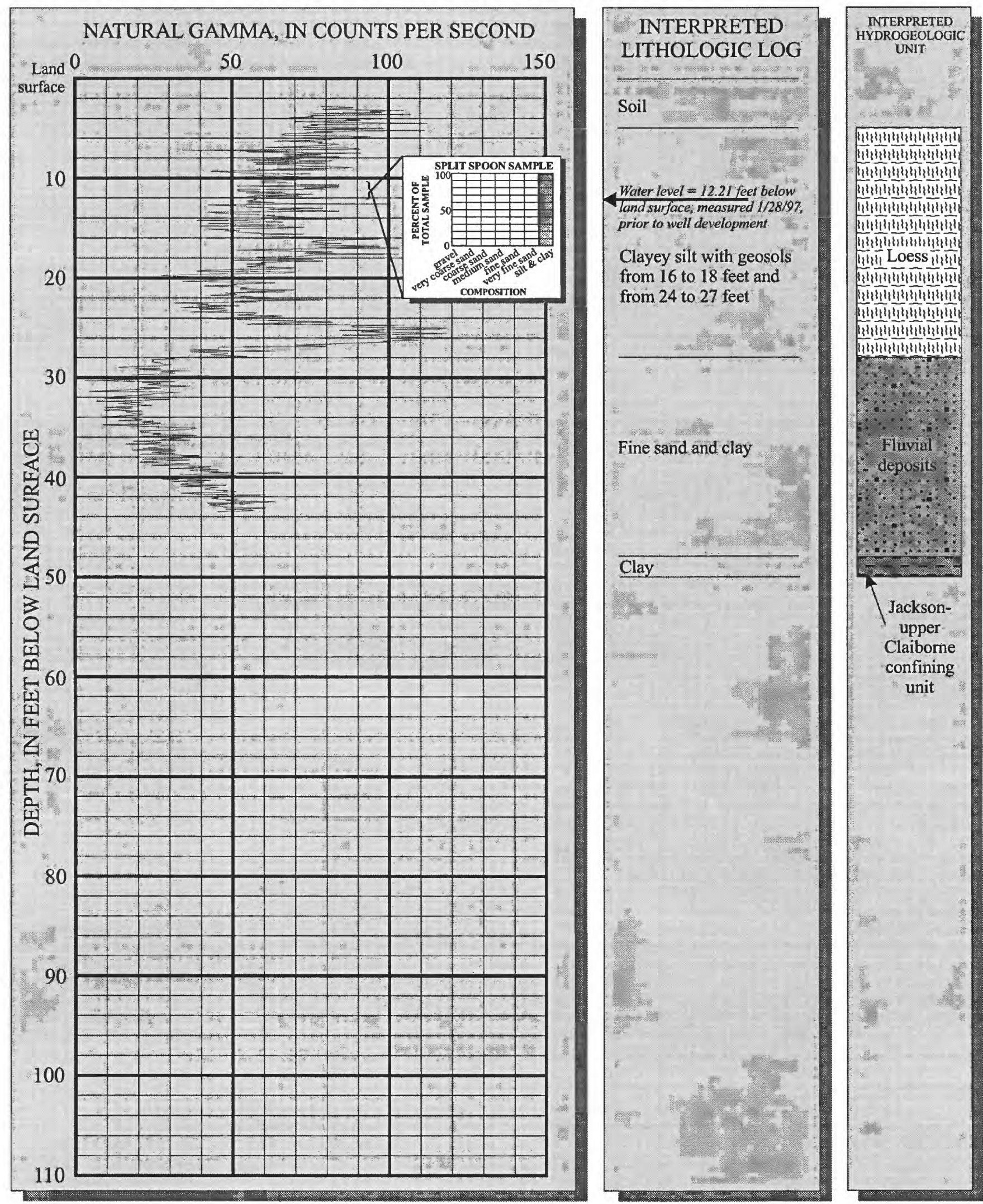

Figure 12. Natural-gamma and lithologic logs and hydrogeologic interpretation for well UR8, Memphis, Tennessee, area. 
Latitude: $35^{\circ} 11^{\prime} 36^{\prime \prime} \quad$ Longitude: $89^{\circ} 53^{\prime} 28^{\prime \prime}$ Altitude: 295 feet above sea level Total well depth: 45 feet

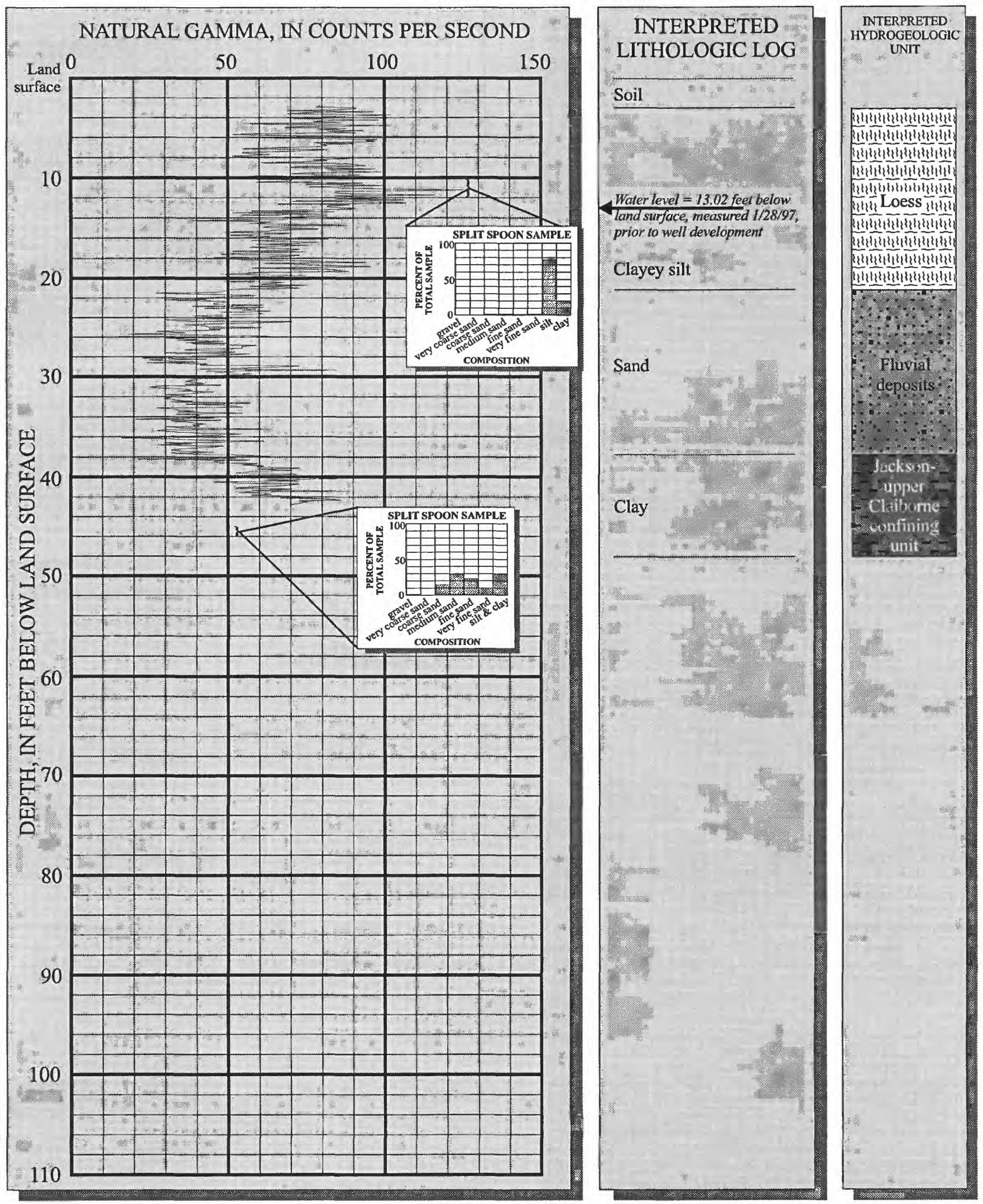

Figure 13. Natural-gamma and lithologic logs and hydrogeologic interpretation for well UR9, Memphis, Tennessee, area. 
Latitude: $35^{\circ} 11^{\prime} 37^{\prime \prime} \quad$ Longitude: $89^{\circ} 54^{\prime} 25^{\prime \prime}$ Altitude: 239 feet above sea level Total well depth: 48 feet

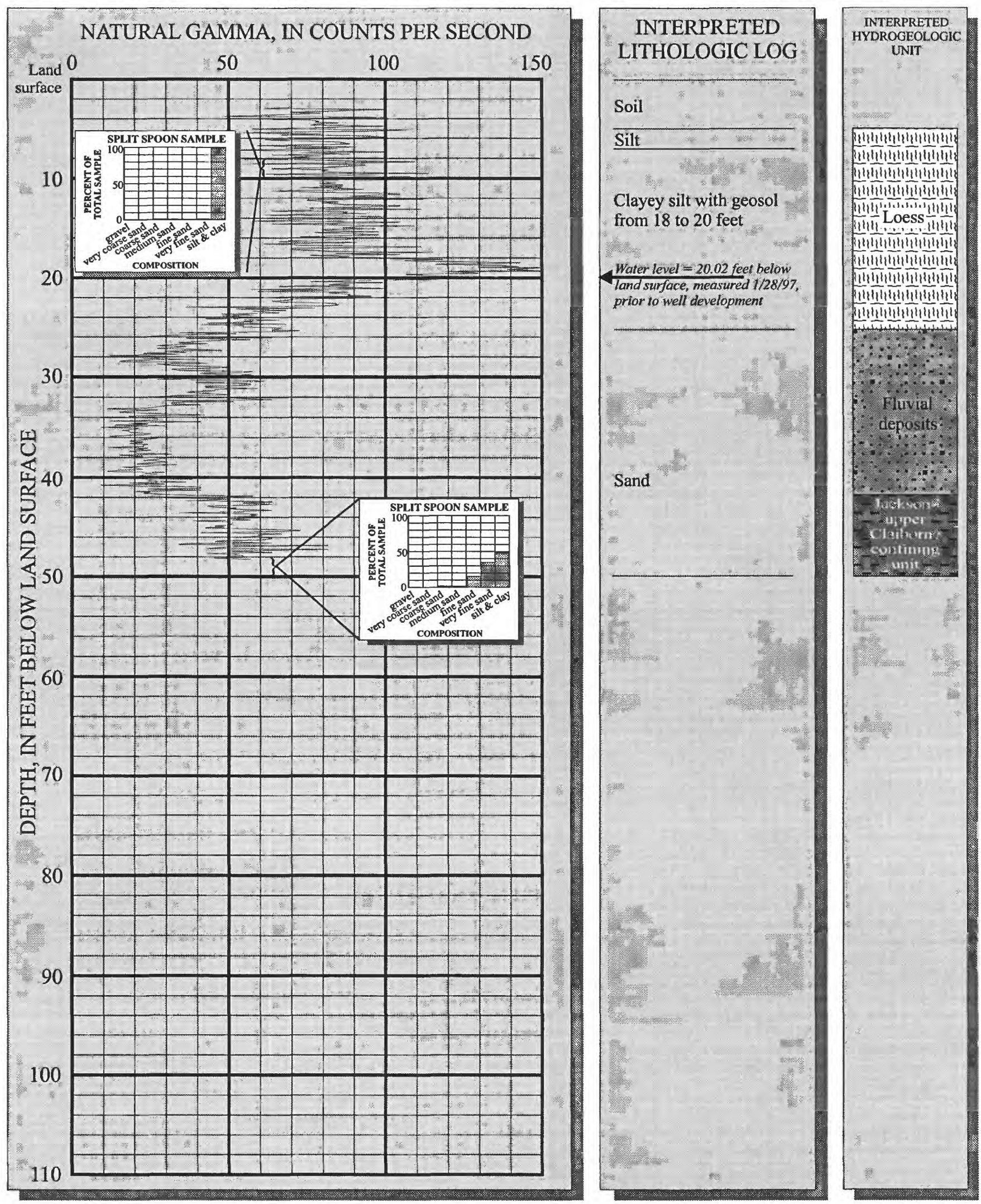

Figure 14. Natural-gamma and lithologic logs and hydrogeologic interpretation for well UR10, Memphis, Tennessee, area. 
Well UR11

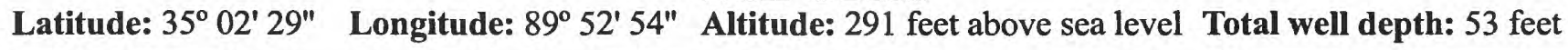

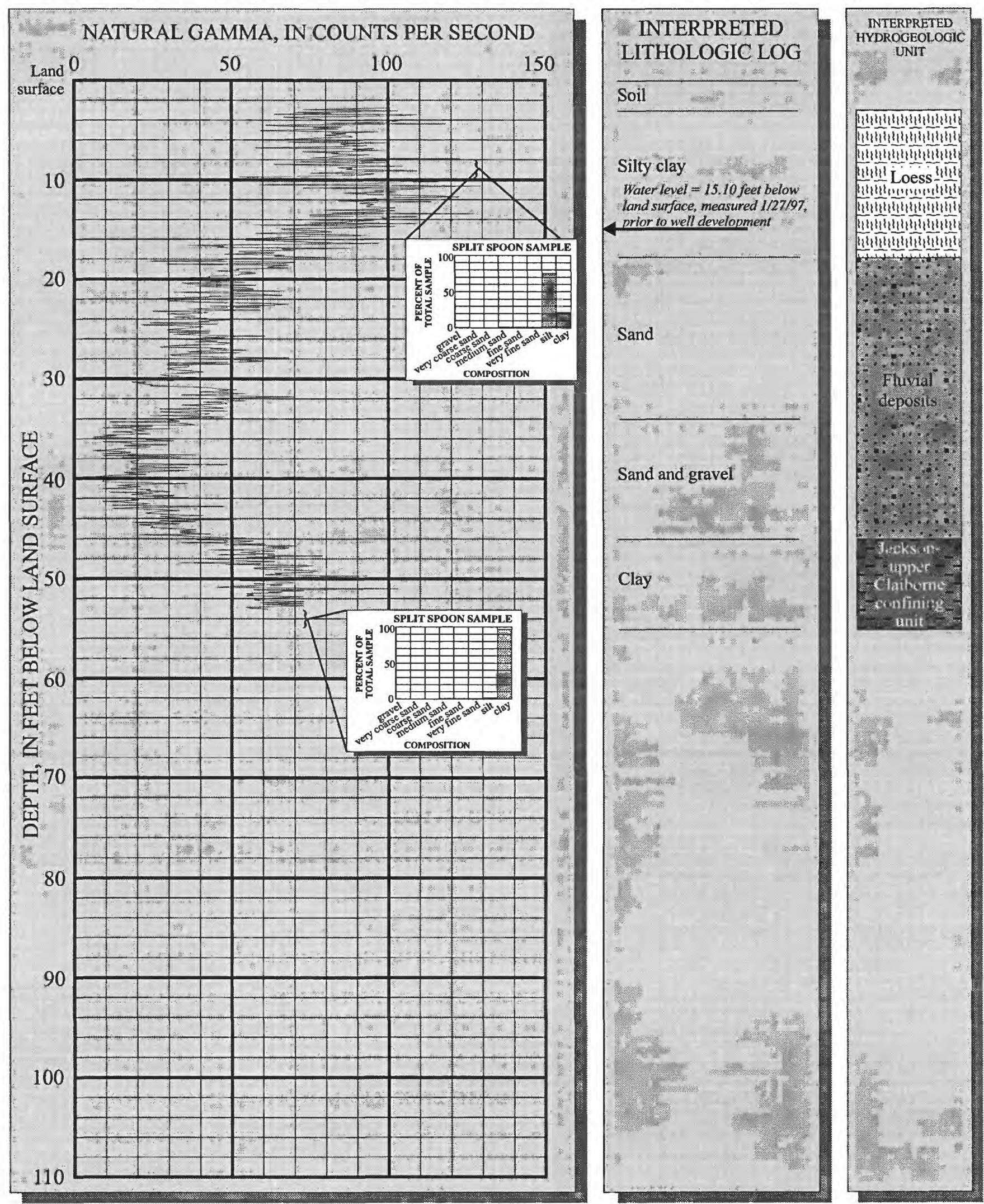

Figure 15. Natural-gamma and lithologic logs and hydrogeologic interpretation for well UR11, Memphis, Tennessee, area. 
Latitude: $35^{\circ} 03^{\prime} 08^{\prime \prime} \quad$ Longitude: $89^{\circ} 52^{\prime} 50^{\prime \prime}$ Altitude: 293 feet above sea level Total well depth: 109 feet
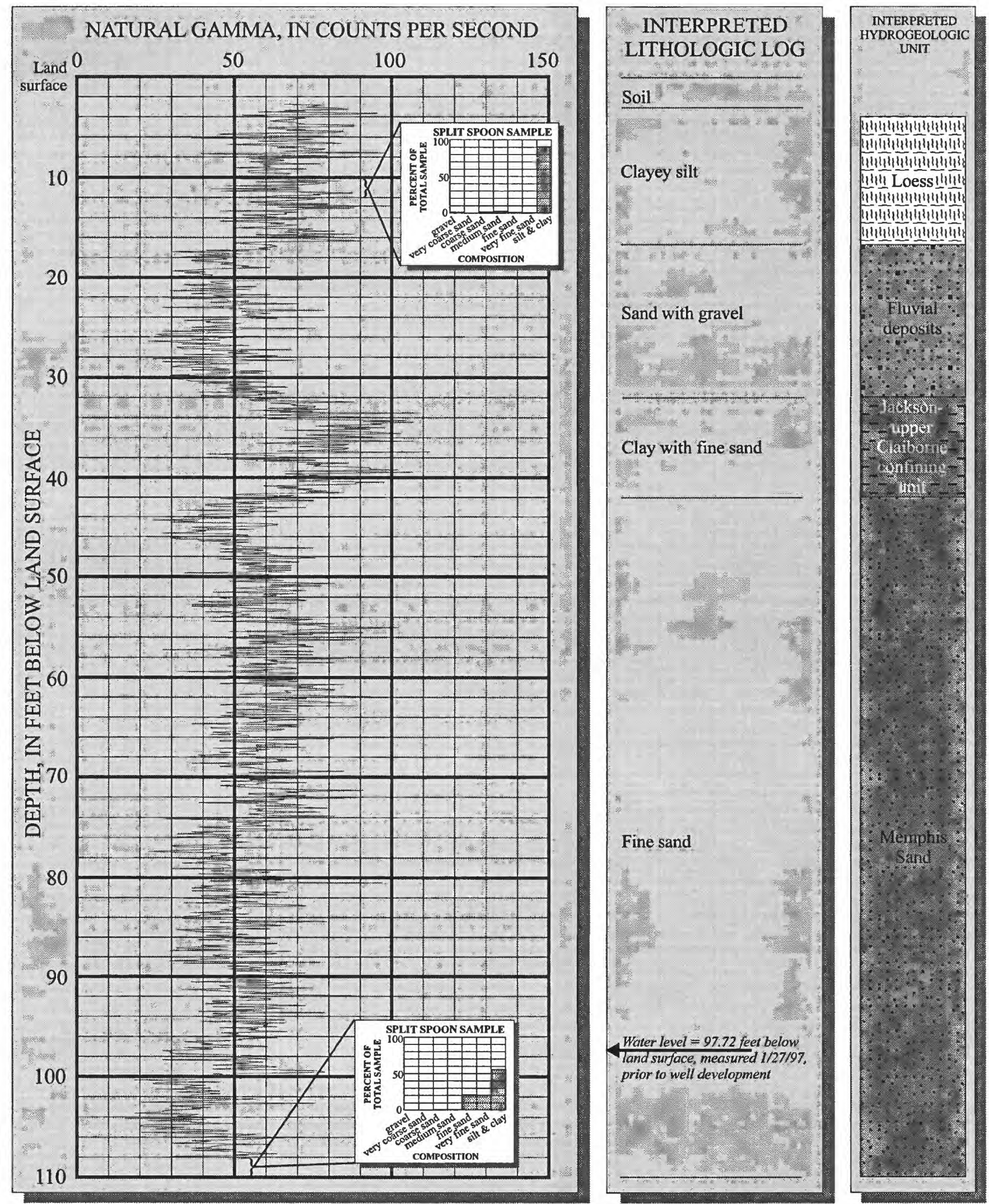

Figure 16. Natural-gamma and lithologic logs and hydrogeologic interpretation for well UR12, Memphis, Tennessee, area. 


\section{Well UR13M}

Latitude: $35^{\circ} 04^{\prime} 43^{\prime \prime} \quad$ Longitude: $89^{\circ} 52^{\prime} 48^{\prime \prime}$ Altitude: 268 feet above sea level Total well depth: 98 feet

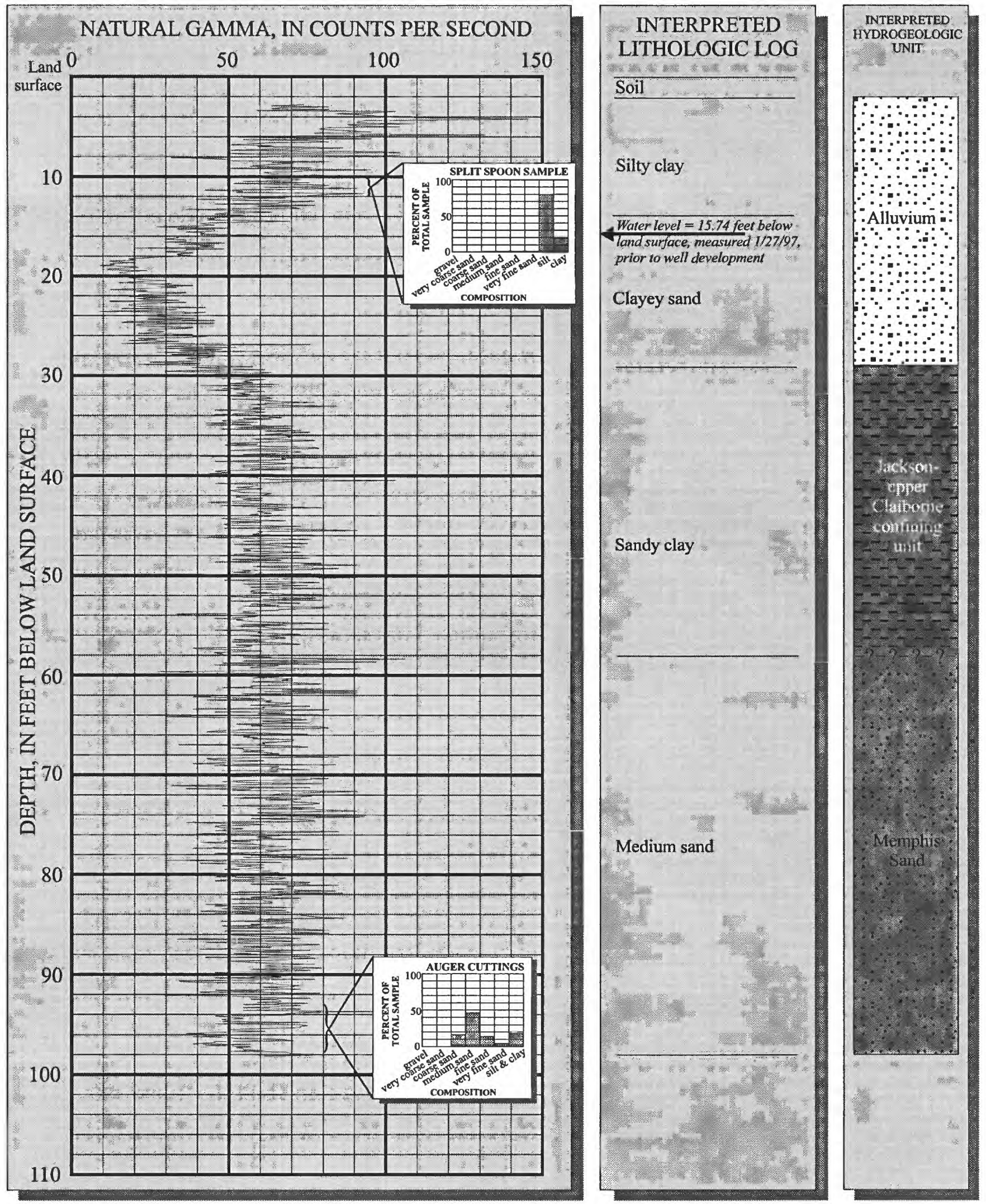

Figure 17. Natural-gamma and lithologic logs and hydrogeologic interpretation for well UR13M, Memphis, Tennessee, area. 


\section{Well UR13S}

Latitude: $35^{\circ} 04^{\prime} 43^{\prime \prime} \quad$ Longitude: $89^{\circ} 52^{\prime} 48^{\prime \prime}$ Altitude: 268 feet above sea level Total well depth: 33 feet

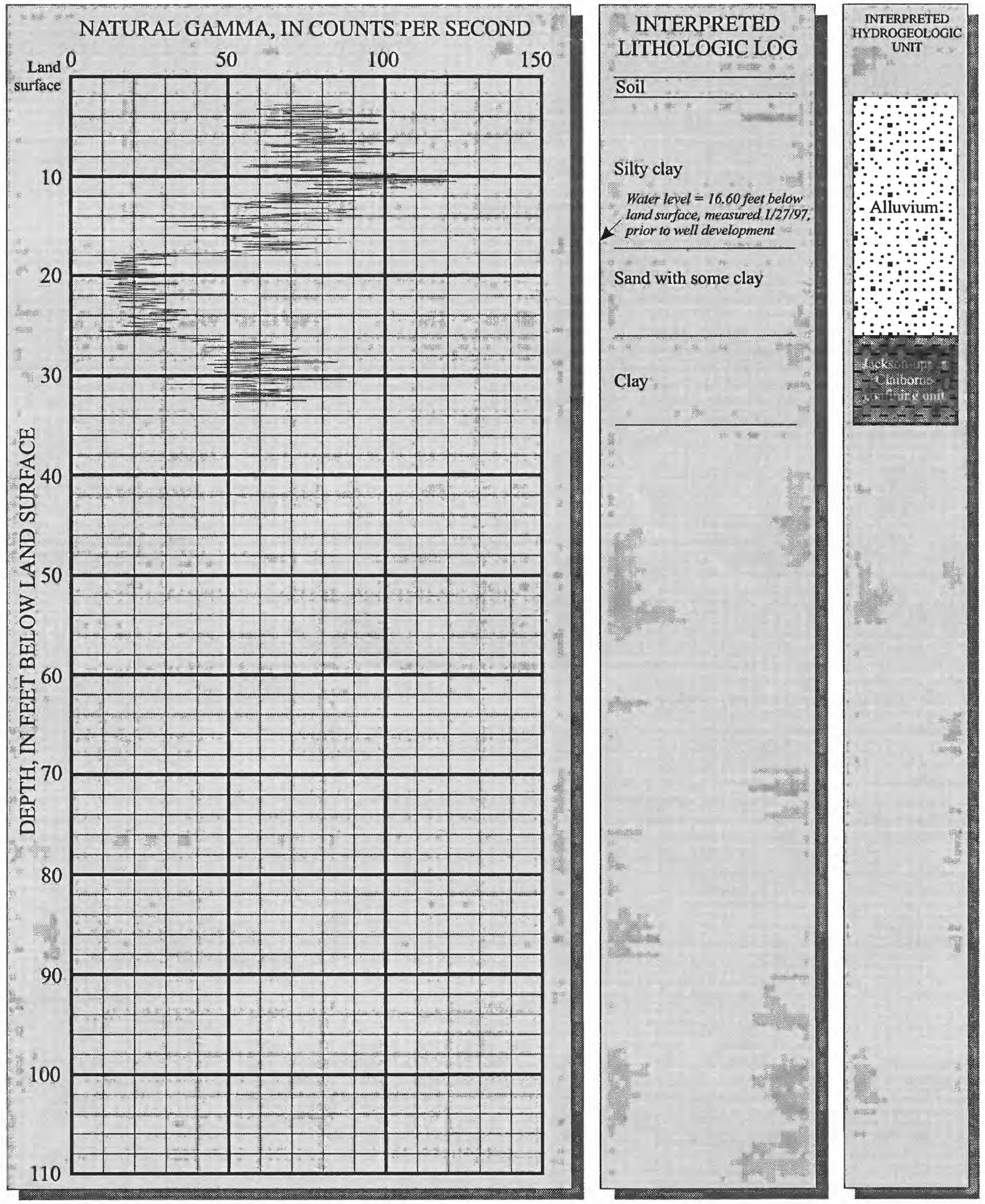

Figure 18. Natural-gamma and lithologic logs and hydrogeologic interpretation for well UR13S, Memphis, Tennessee, area. 
Latitude: $35^{\circ} 12^{\prime} 45^{\prime \prime} \quad$ Longitude: $89^{\circ} 50^{\prime} 50^{\prime \prime}$ Altitude: 311 feet above sea level Total well depth: 88 feet

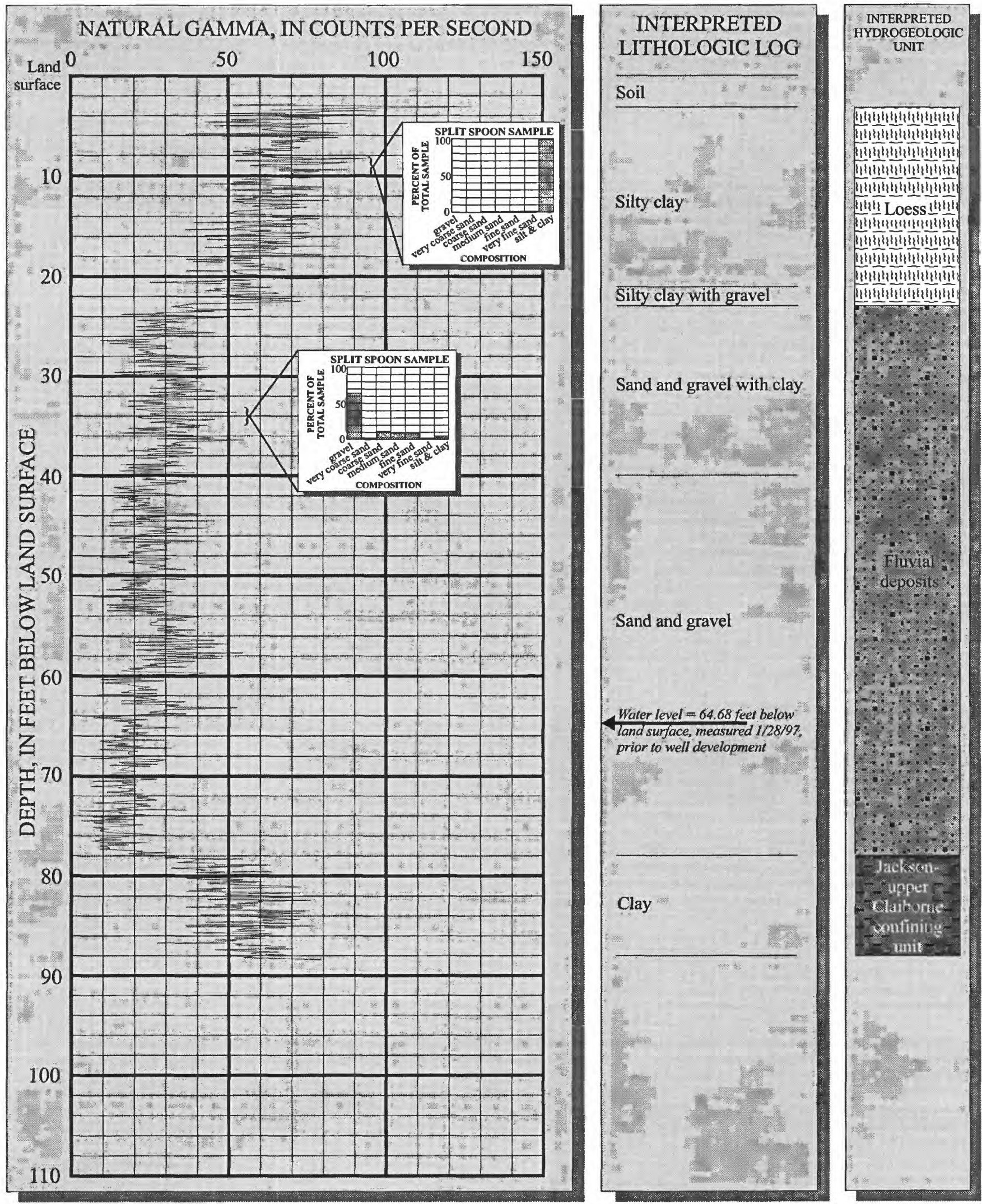

Figure 19. Natural-gamma and lithologic logs and hydrogeologic interpretation for well UR16, Memphis, Tennessee, area. 
Latitude: $35^{\circ} 13^{\prime} 19^{\prime \prime} \quad$ Longitude: $89^{\circ} 50^{\prime} 44^{\prime \prime}$ Altitude: 304 feet above sea level Total well depth: 48 feet

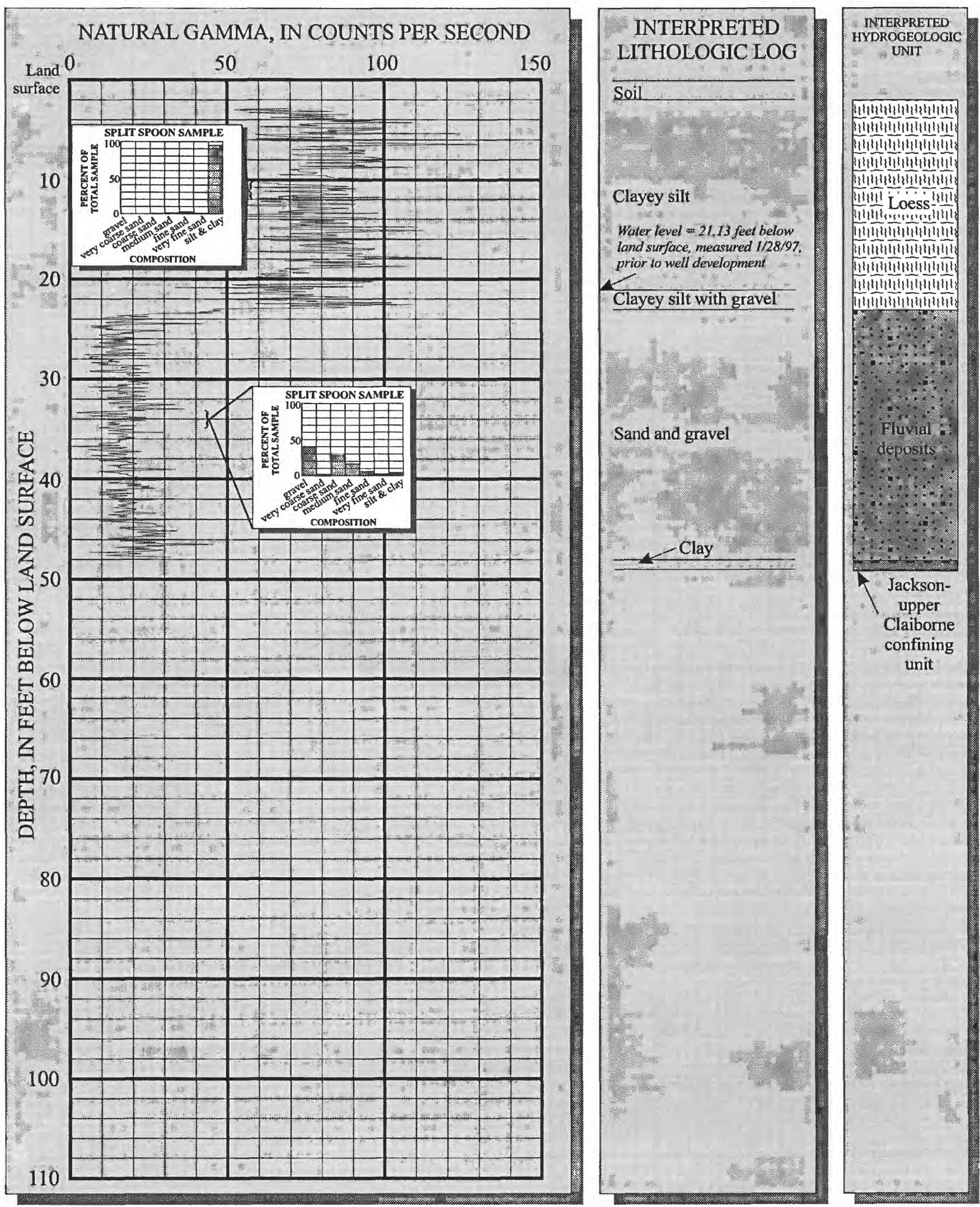

Figure 20. Natural-gamma and lithologic logs and hydrogeologic interpretation for well UR17, Memphis, Tennessee, area. 
Latitude: $35^{\circ} 11^{\prime} 53^{\prime \prime} \quad$ Longitude: $89^{\circ} 49^{\prime} 42^{\prime \prime}$ Altitude: 265 feet above sea level Total well depth: 68 feet

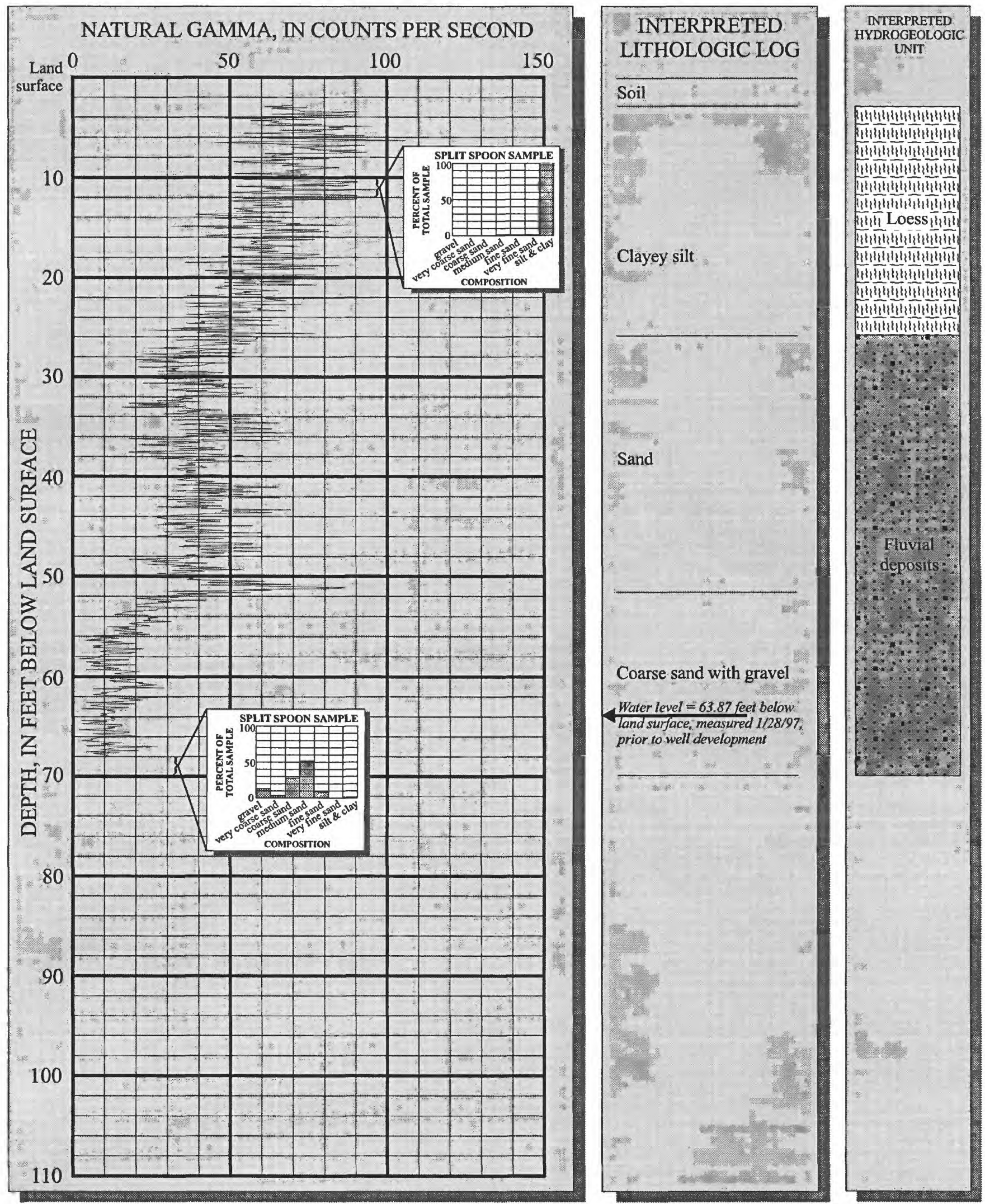

Figure 21. Natural-gamma and lithologic logs and hydrogeologic interpretation for well UR18, Memphis, Tennessee, area. 
Latitude: $35^{\circ} 10^{\prime} 57^{\prime \prime} \quad$ Longitude: $89^{\circ} 49^{\prime} 56^{\prime \prime}$ Altitude: 270 feet above sea level Total well depth: 65 feet

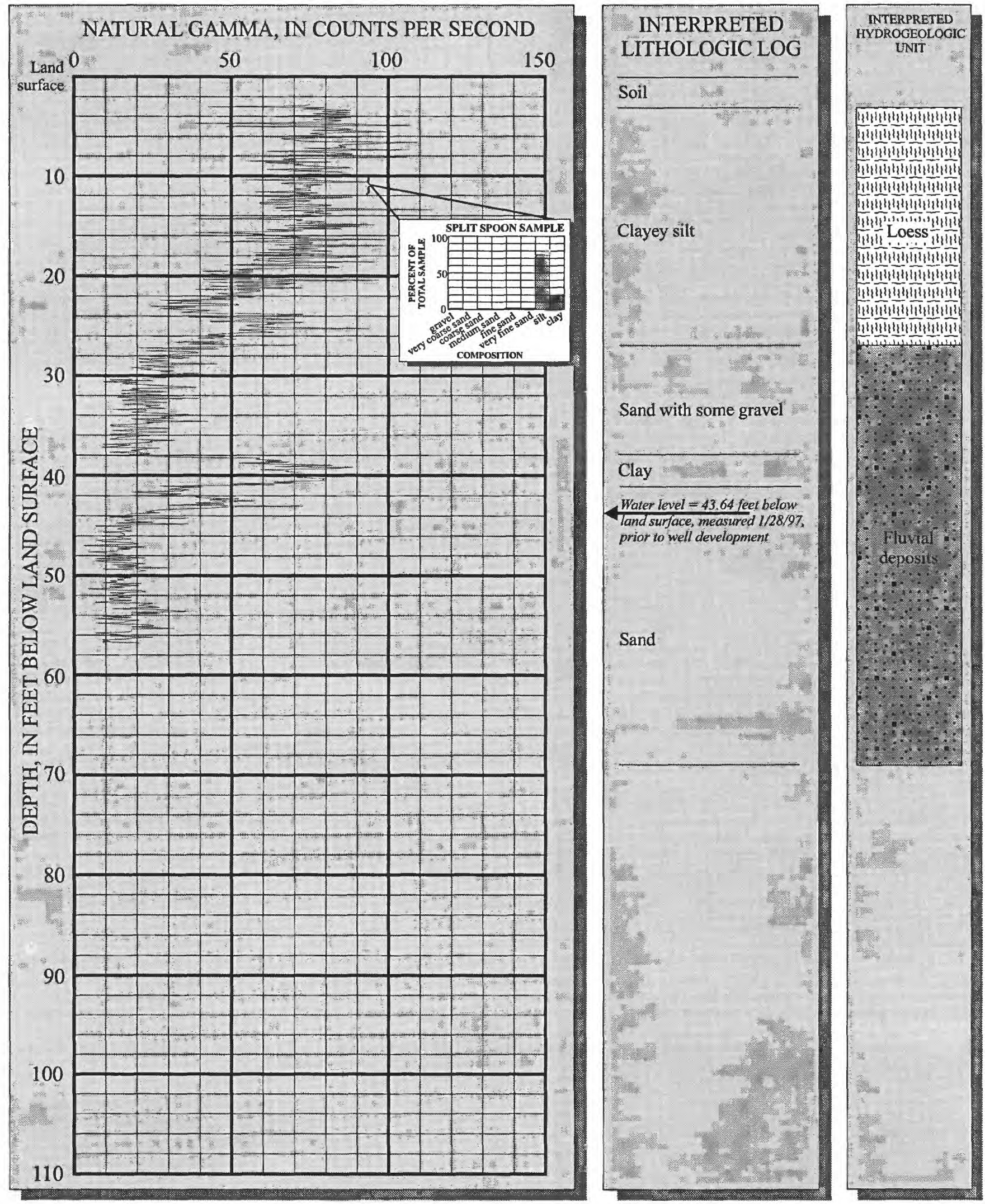

Figure 22. Natural-gamma and lithologic logs and hydrogeologic interpretation for well UR19, Memphis, Tennessee, area. 
Latitude: $35^{\circ} 06^{\prime} 43^{\prime \prime} \quad$ Longitude: $89^{\circ} 50^{\prime} 20^{\prime \prime}$ Altitude: 268 feet above sea level Total well depth: 76 feet

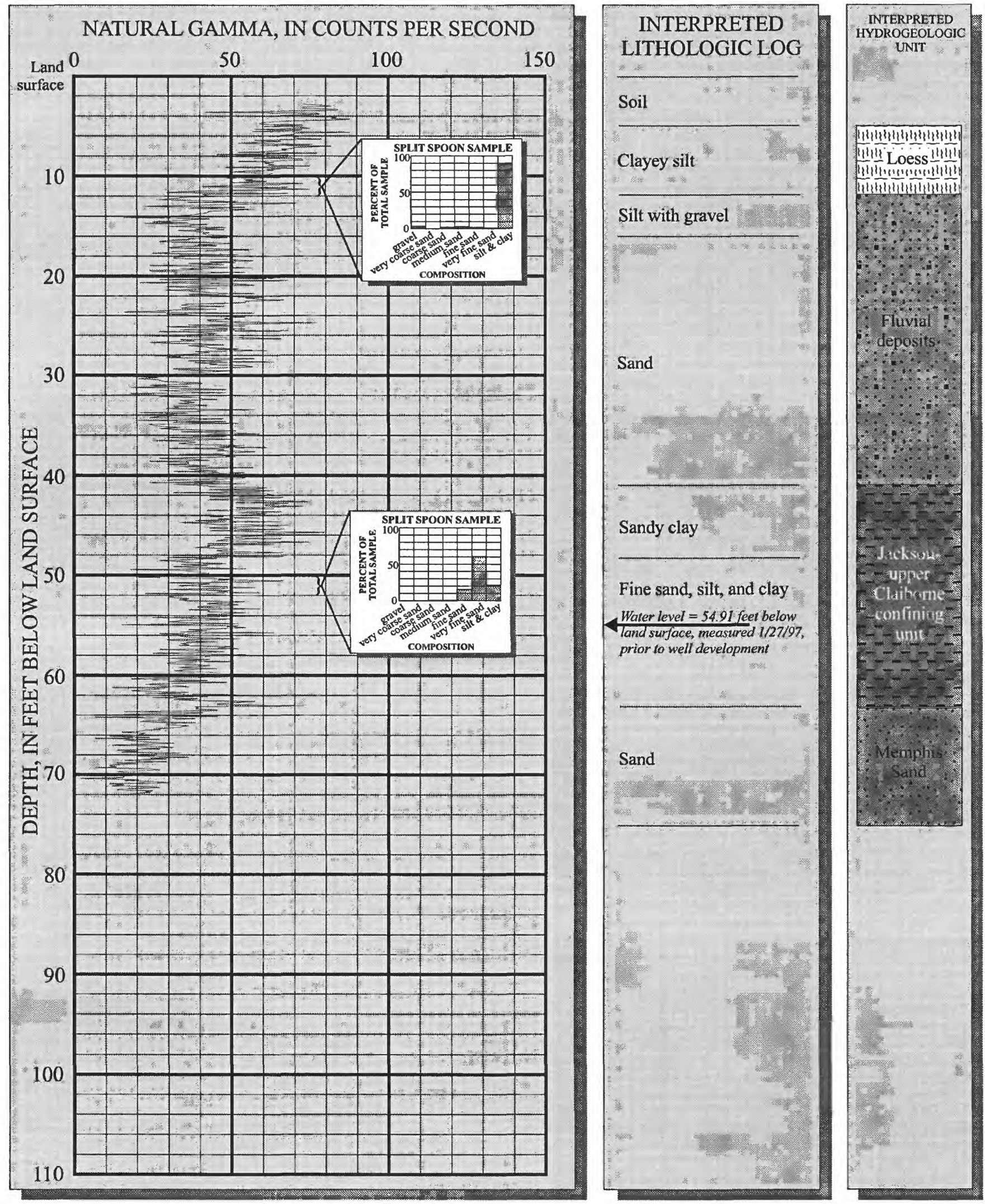

Figure 23. Natural-gamma and lithologic logs and hydrogeologic interpretation for well UR20, Memphis, Tennessee, area. 
Well UR21

Latitude: $35^{\circ} 03^{\prime} 48^{\prime \prime} \quad$ Longitude: $89^{\circ} 50^{\prime} 11^{\prime \prime}$ Altitude: 283 feet above sea level Total well depth: 88 feet

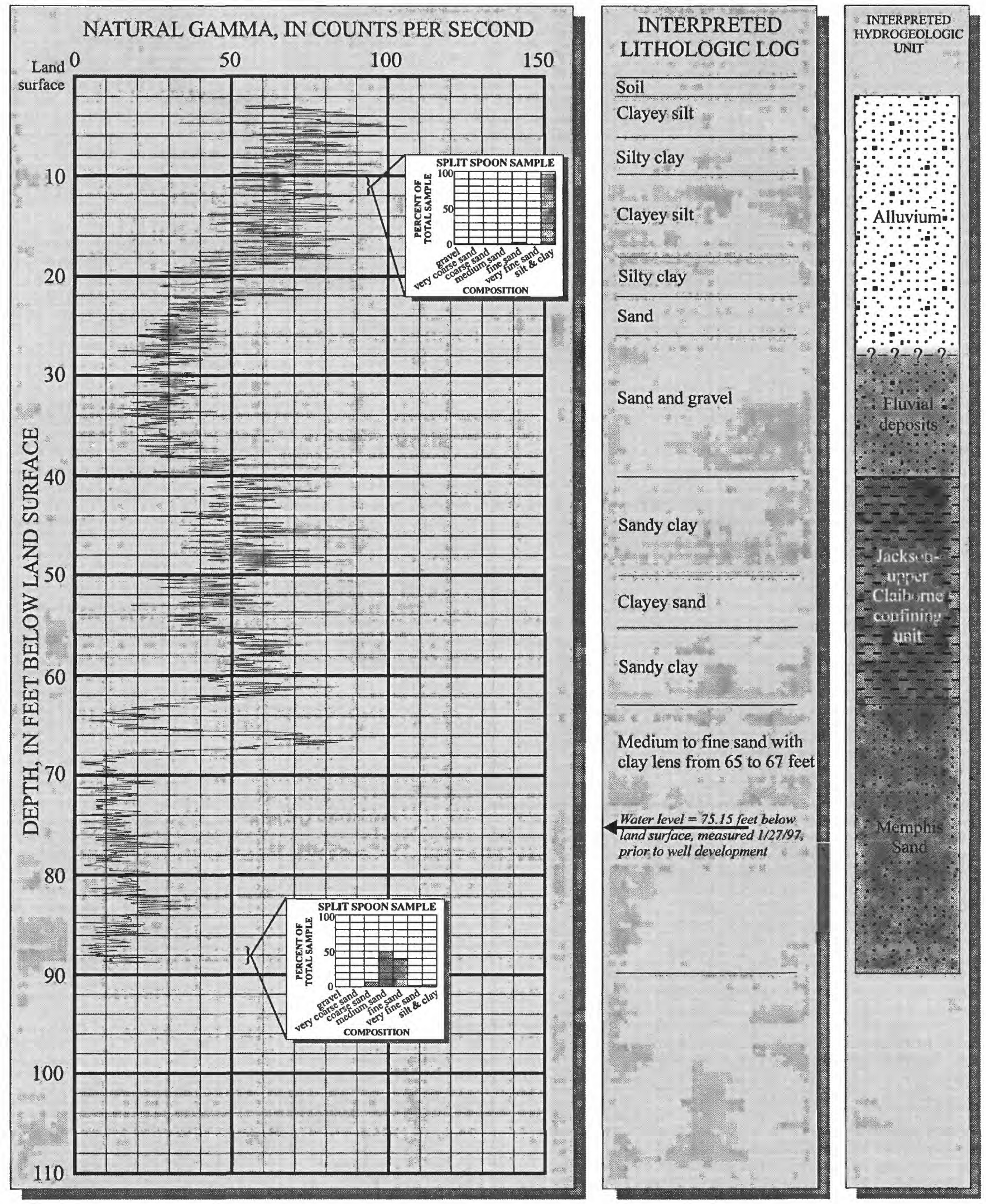

Figure 24. Natural-gamma and lithologic logs and hydrogeologic interpretation for well UR21, Memphis, Tennessee, area. 
Latitude: $35^{\circ} 03^{\prime} 20^{\prime \prime} \quad$ Longitude: $89^{\circ} 50^{\prime} 29^{\prime \prime}$ Altitude: 286 feet above sea level Total well depth: 98 feet
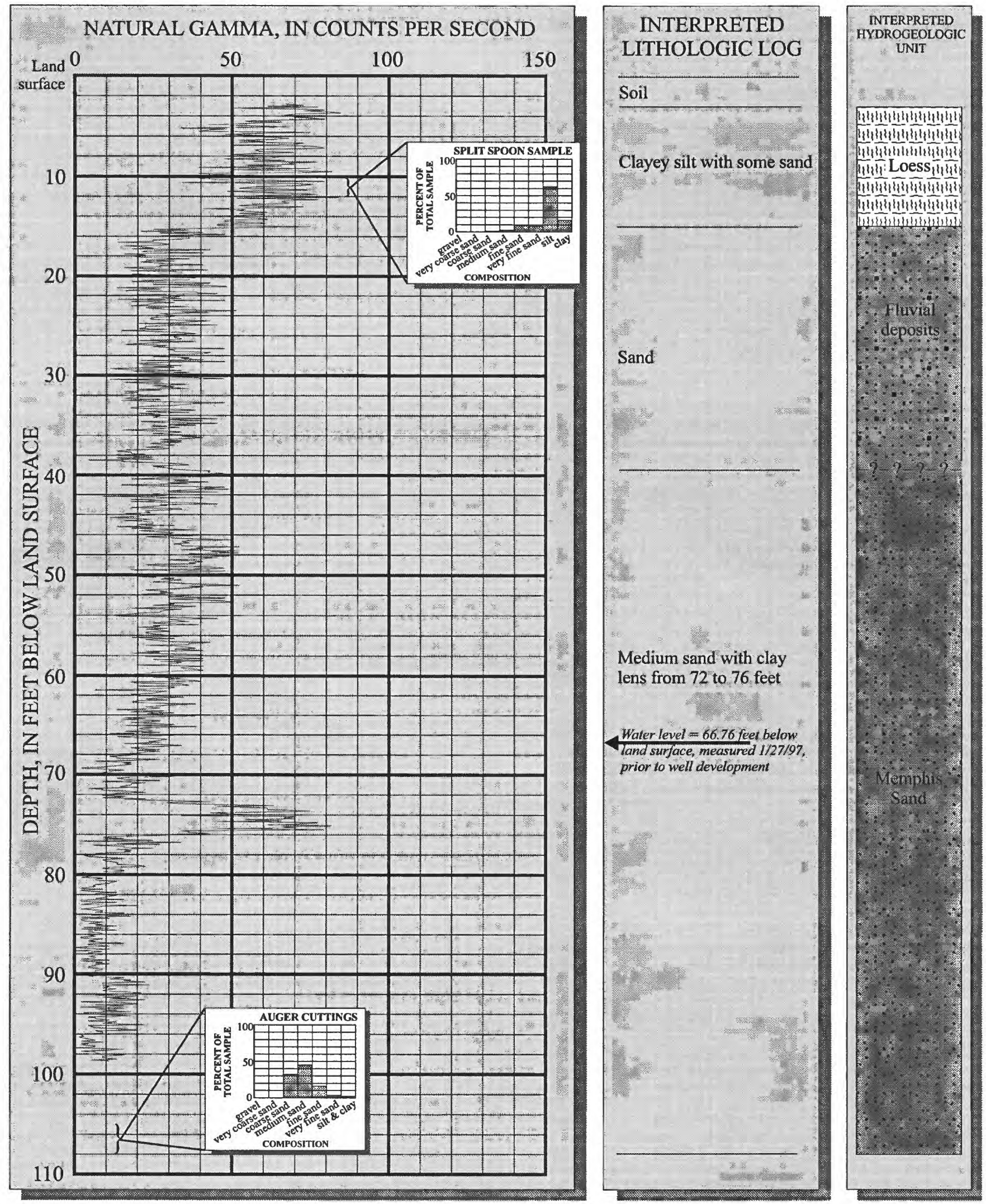

Figure 25. Natural-gamma and lithologic logs and hydrogeologic interpretation for well UR22, Memphis, Tennessee, area. 
Latitude: $35^{\circ} 01^{\prime} 52^{\prime \prime} \quad$ Longitude: $89^{\circ} 48^{\prime} 29^{\prime \prime}$ Altitude: 328 feet above sea level Total well depth: 43 feet
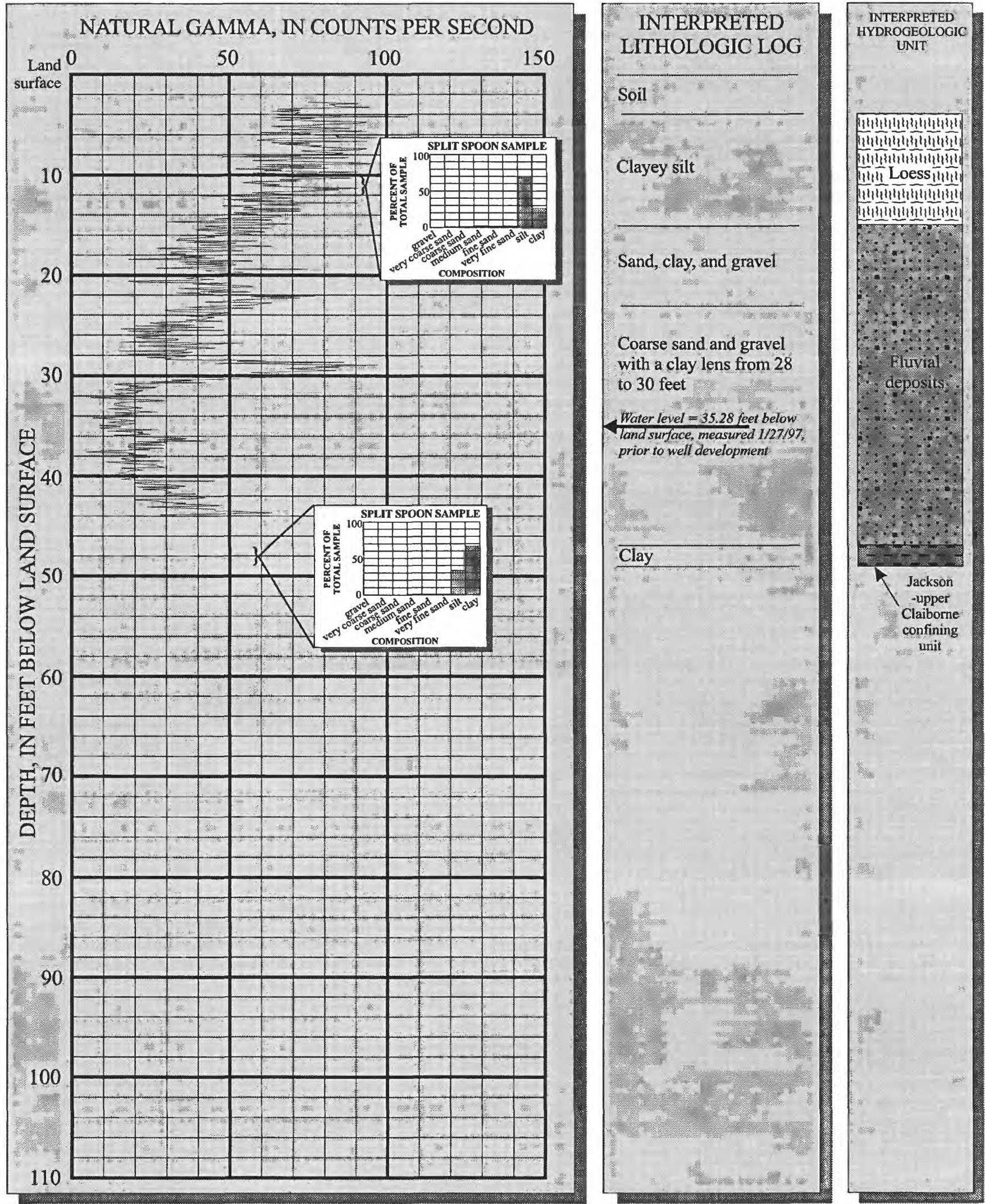

Figure 26. Natural-gamma and lithologic logs and hydrogeologic interpretation for well UR23, Memphis, Tennessee, area. 
Latitude: $35^{\circ} 02^{\prime} 24^{\prime \prime} \quad$ Longitude: $89^{\circ} 48^{\prime} 55^{\prime \prime}$ Altitude: 295 feet above sea level Total well depth: 100 feet

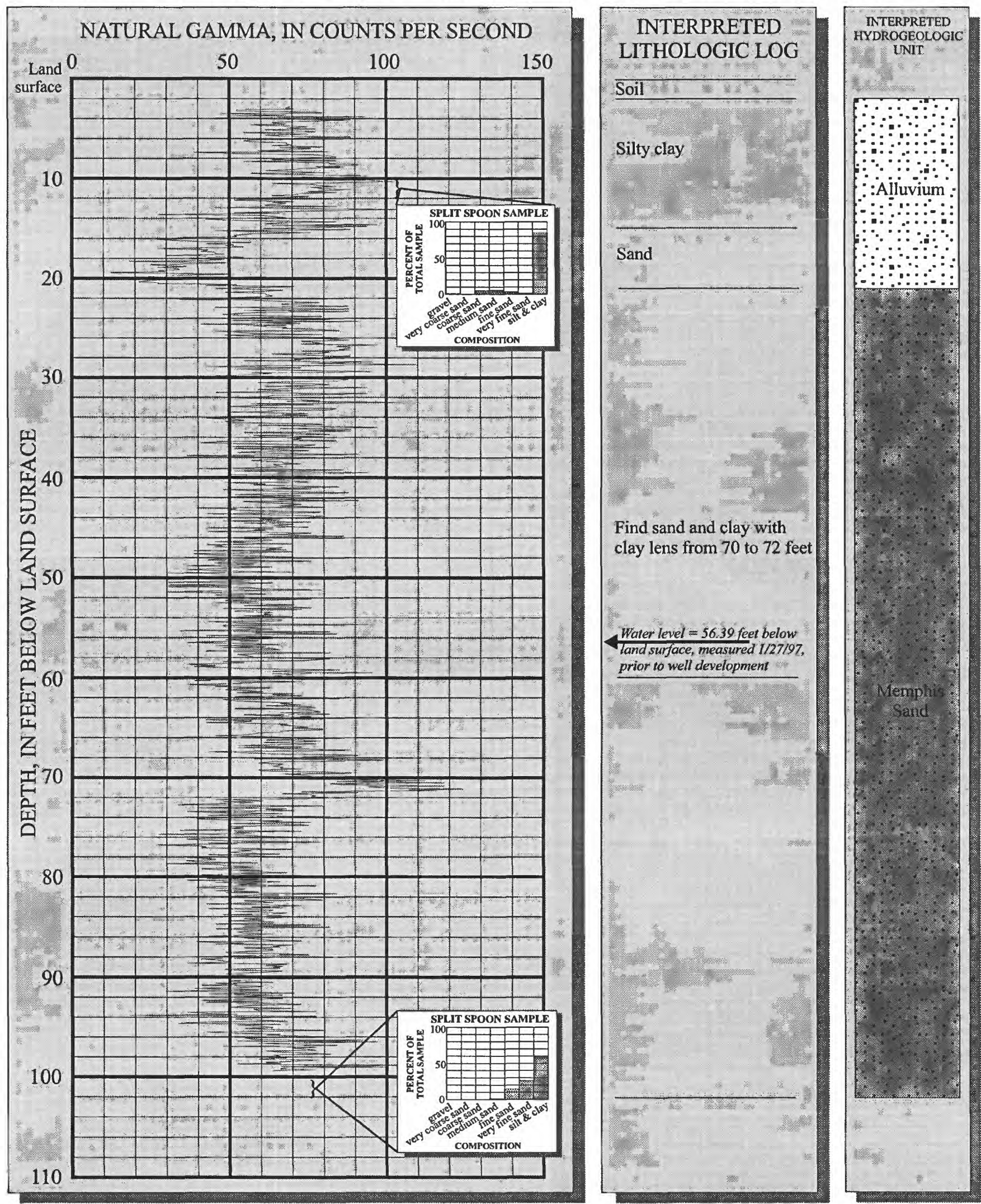

Figure 27. Natural-gamma and lithologic logs and hydrogeologic interpretation for well UR24, Memphis, Tennessee, area. 


\section{Well UR25M}

Latitude: $35^{\circ} 02^{\prime} 59^{\prime \prime} \quad$ Longitude: $89^{\circ} 49^{\prime} 05^{\prime \prime}$ Altitude: 291 feet above sea level Total well depth: 94 feet

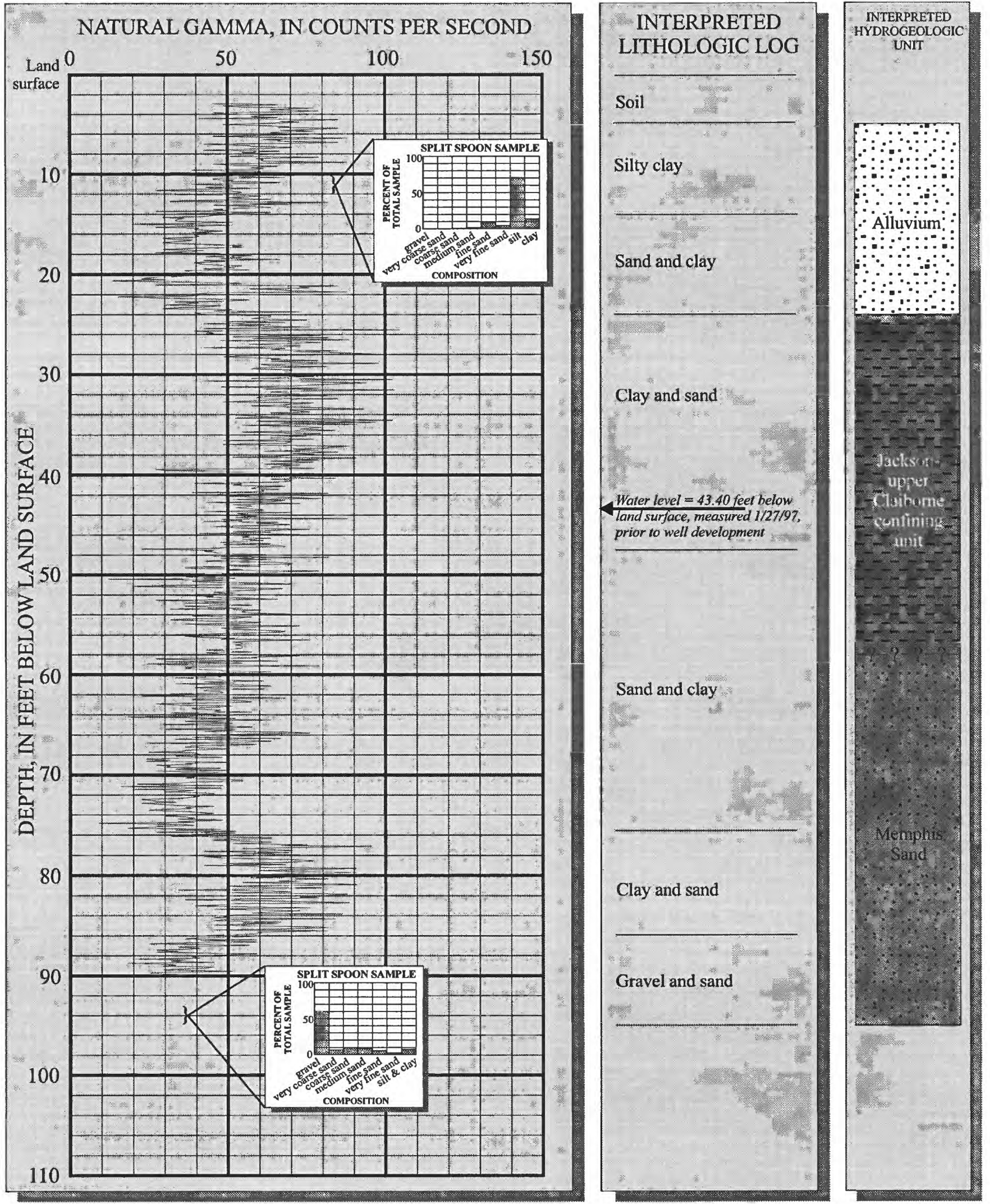

Figure 28. Natural-gamma and lithologic logs and hydrogeologic interpretation for well UR25M, Memphis, Tennessee, area. 
Latitude: $35^{\circ} 02^{\prime} 59^{\prime \prime} \quad$ Longitude: $89^{\circ} 49^{\prime} 05^{\prime \prime}$ Altitude: 291 feet above sea level Total well depth: 43 feet

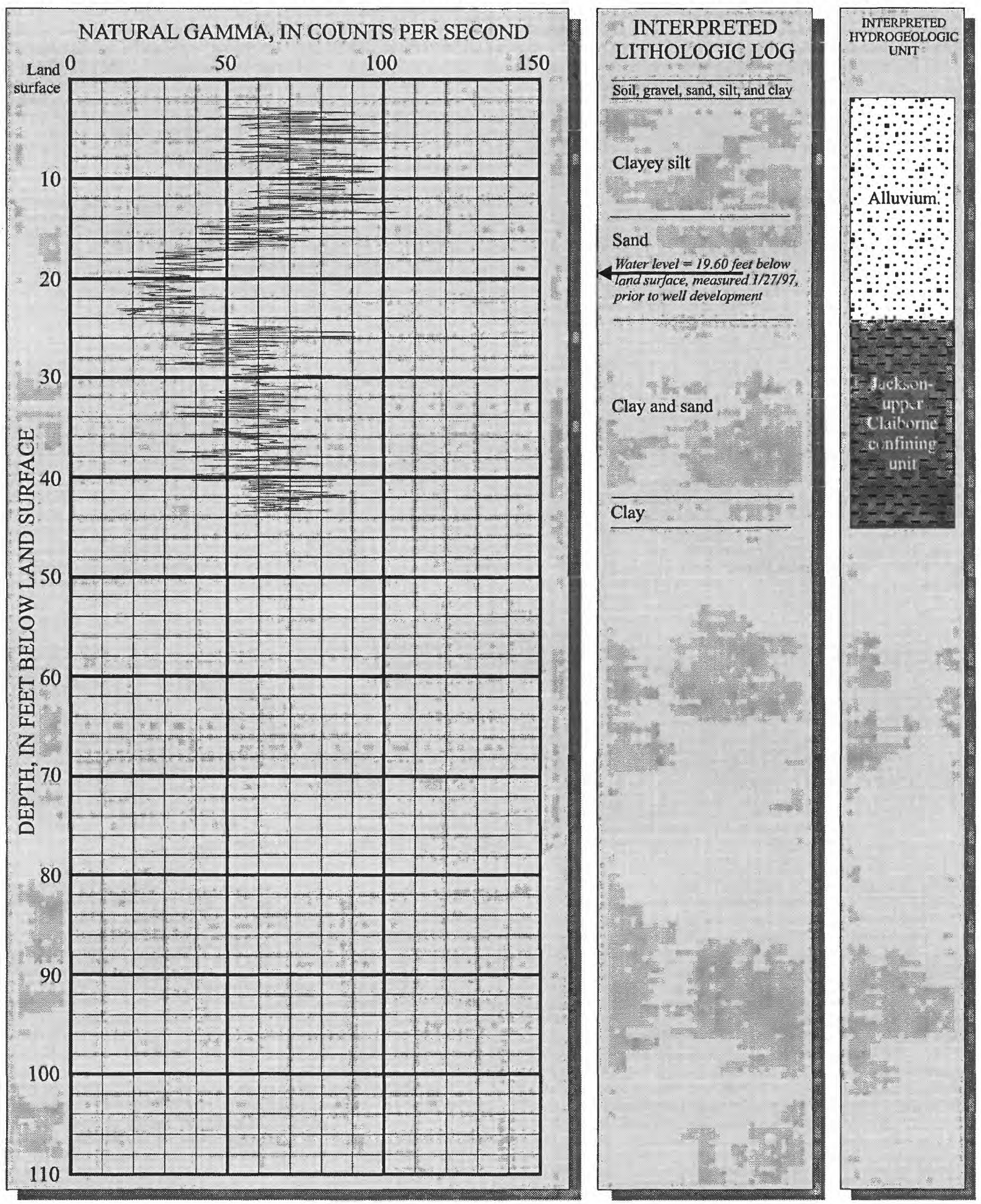

Figure 29. Natural-gamma and lithologic logs and hydrogeologic interpretation for well UR25S, Memphis, Tennessee, area. 
Well UR26

Latitude: $35^{\circ} 05^{\prime} 44^{\prime \prime} \quad$ Longitude: $89^{\circ} 47^{\prime} 39^{\prime \prime}$ Altitude: 300 feet above sea level Total well depth: 108 feet
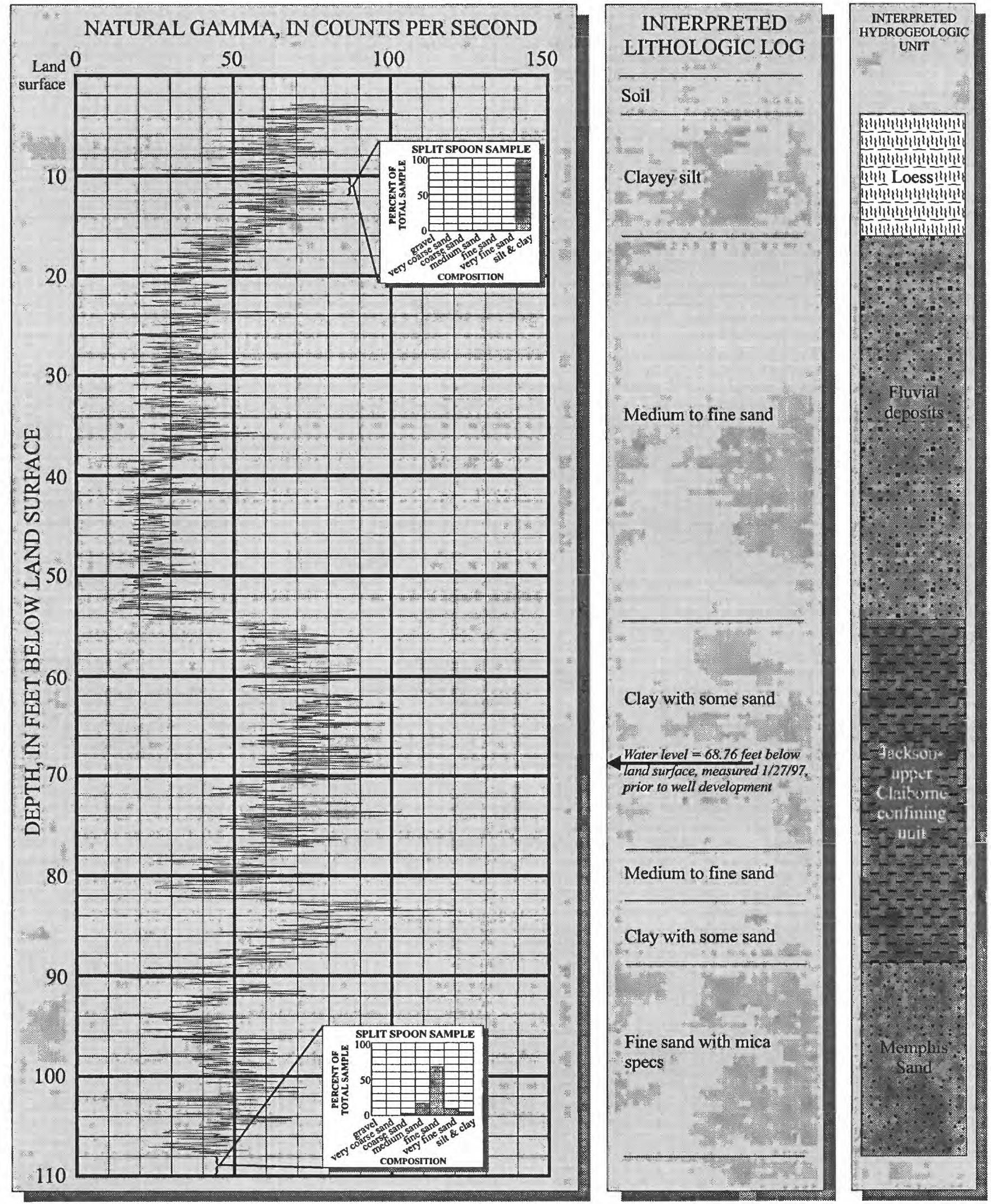

Figure 30. Natural-gamma and lithologic logs and hydrogeologic interpretation for well UR26, Memphis, Tennessee, area. 
Latitude: $35^{\circ} 06^{\prime} 42^{\prime \prime} \quad$ Longitude: $89^{\circ} 49^{\prime} 12^{\prime \prime}$ Altitude: 269 feet above sea level Total well depth: 30 feet

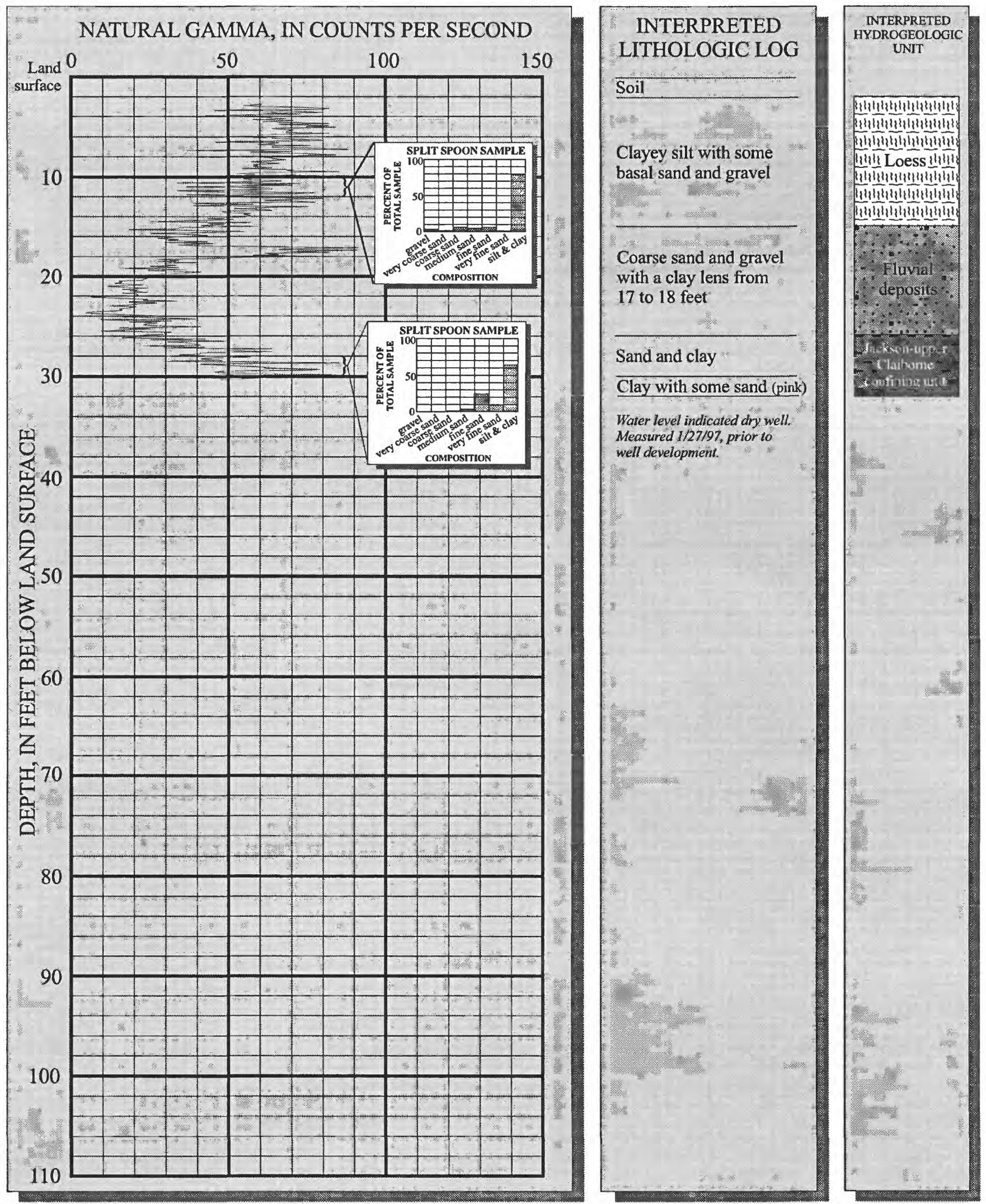

Figure 31. Natural-gamma and lithologic logs and hydrogeologic interpretation for well UR27, Memphis, Tennessee, area. 
Well UR28

Latitude: $35^{\circ} 11^{\prime} 08^{\prime \prime} \quad$ Longitude: $89^{\circ} 46^{\prime} 32^{\prime \prime}$ Altitude: 362 feet above sea level Total well depth: 39 feet

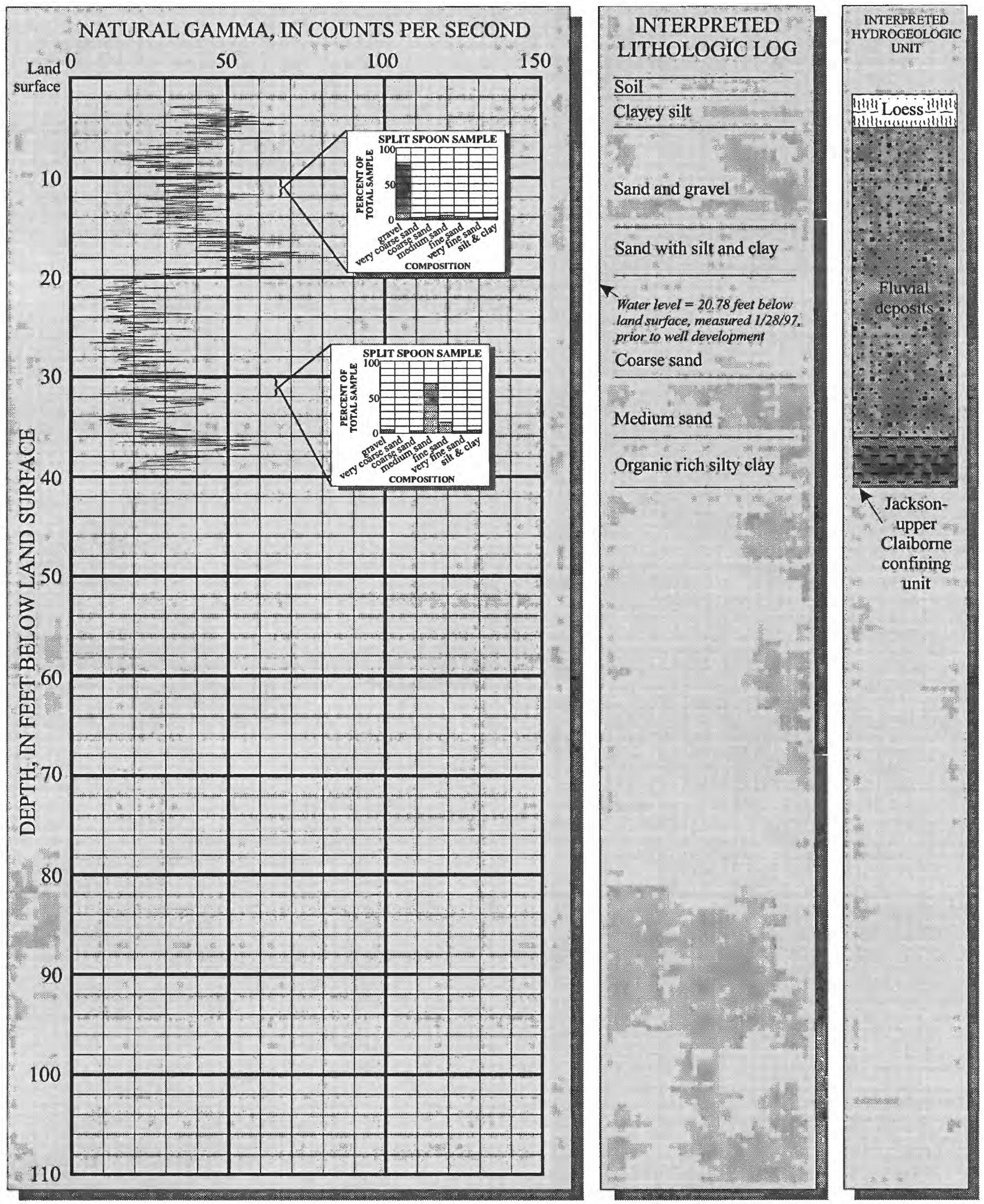

Figure 32. Natural-gamma and lithologic logs and hydrogeologic interpretation for well UR28, Memphis, Tennessee, area. 
Latitude: $35^{\circ} 11^{\prime} 47^{\prime \prime} \quad$ Longitude: $89^{\circ} 48^{\prime} 27^{\prime \prime}$ Altitude: 290 feet above sea level Total well depth: 87 feet

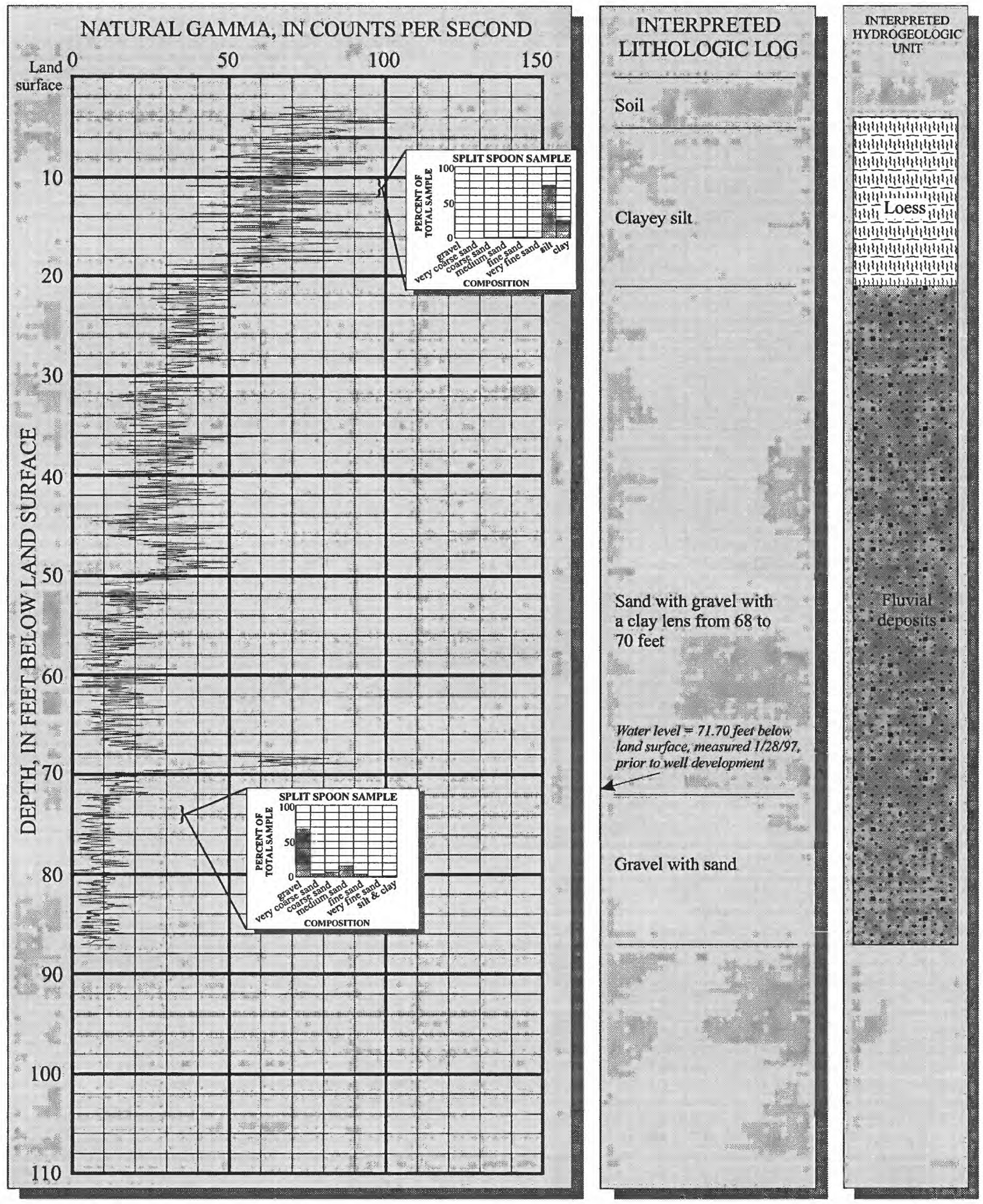

Figure 33. Natural-gamma and lithologic logs and hydrogeologic interpretation for well UR29, Memphis, Tennessee, area. 
Well UR30

Latitude: $35^{\circ} 13^{\prime} 43^{\prime \prime} \quad$ Longitude: $89^{\circ} 49^{\prime} 18^{\prime \prime}$ Altitude: 307 feet above sea level Total well depth: 80 feet

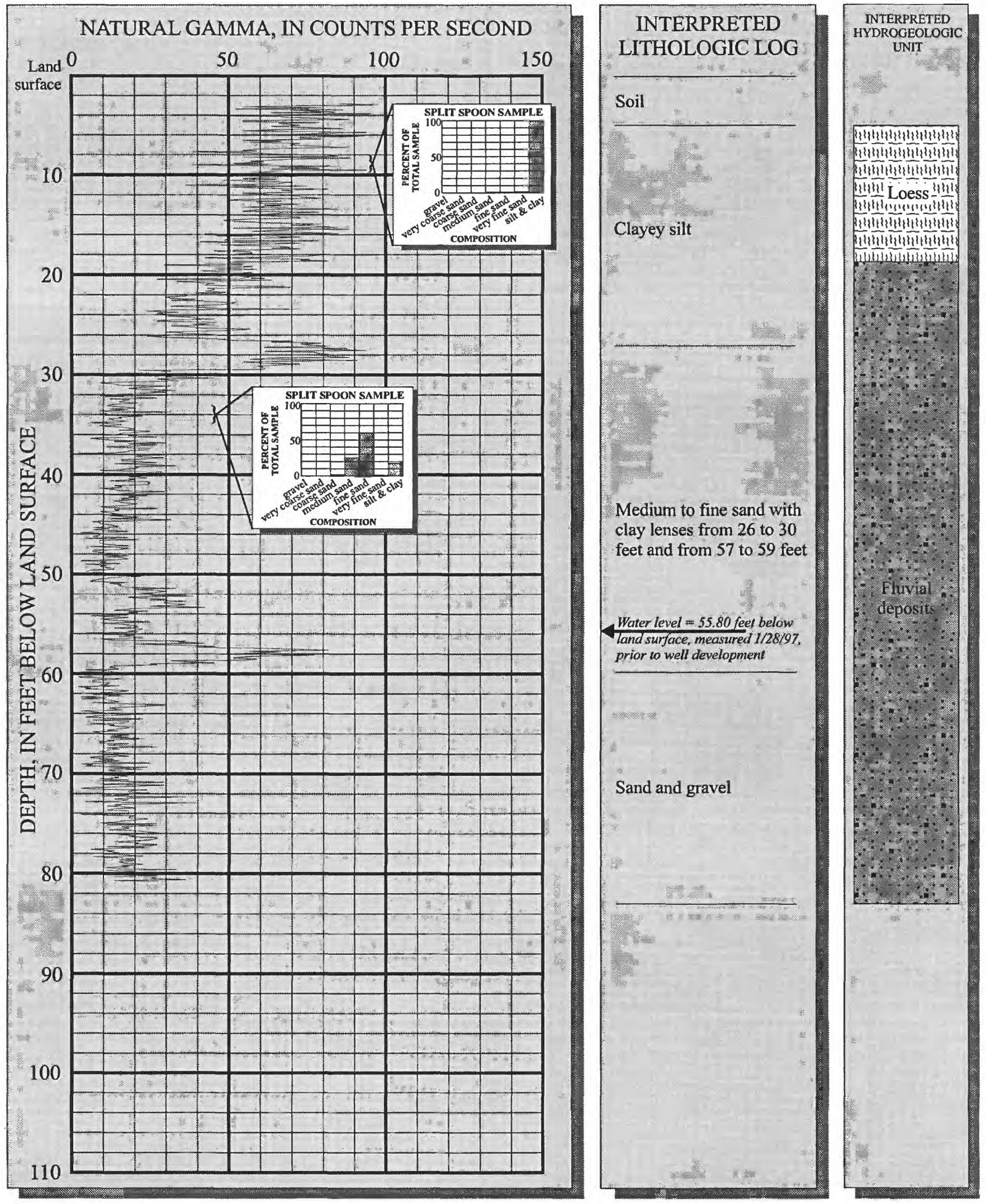

Figure 34. Natural-gamma and lithologic logs and hydrogeologic interpretation for well UR30, Memphis, Tennessee, area. 
Latitude: 35 04' 25" Longitude: $89^{\circ} 59^{\prime} 39^{\prime \prime}$ Altitude: 235 feet above sea level Total well depth: 43 feet

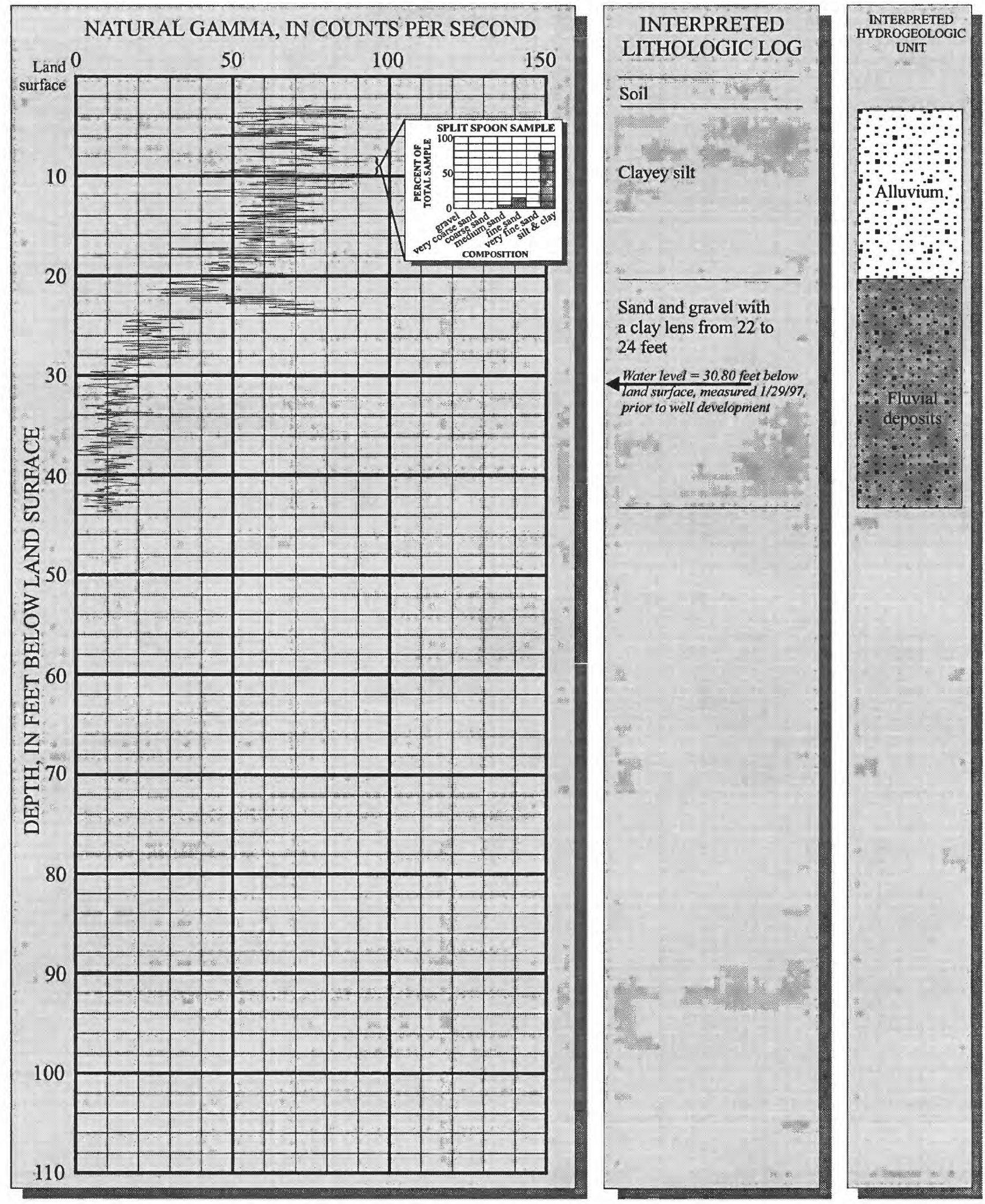

Figure 35. Natural-gamma and lithologic logs and hydrogeologic interpretation for well UR31, Memphis, Tennessee, area. 